\title{
Analysis of Distributed-Generation Photovoltaic Deployment, Installation Time and Cost, Market Barriers, and Policies in China
}

\author{
Fang Zhang, ${ }^{\mathrm{a}, \mathrm{b},{ }^{*}}$ Hao Deng, ${ }^{\mathrm{c}}$ Robert Margolis, ${ }^{\mathrm{d}} \mathrm{Jun} \mathrm{Su}^{\mathrm{e}}$
}

${ }^{\mathrm{a}}$ School of Public Policy and Management, Tsinghua University, 30 Shuang Tsing Road, Haidian

District, Beijing, 100084, China, zhangfang0403@ gmail.com

${ }^{\mathrm{b}}$ Fletcher School of Law and Diplomacy, Tufts University, 160 Packard Ave., Medford, MA,

02155, United States, zhangfang0403@gmail.com

${ }^{c}$ School of Forestry \& Environmental Studies, Yale University, 195 Prospect Street, New Haven, CT, 06511, United States, hao.deng@yale.edu

${ }^{\mathrm{d}}$ National Renewable Energy Laboratory, 901 D. Street, S.W. Suite 930, Washington, D.C. 20024-2157, United States, Robert.Margolis@nrel.gov

${ }^{\mathrm{e}}$ School of Public Policy and Management, Tsinghua University, 30 Shuang Tsing Road, Haidian

District, Beijing, 100084, China, sujun@mail.tsinghua.edu.cn

*Corresponding author: zhangfang0403@gmail.com, Phone number: +1 8572044860 
Beginning in 2013, China's photovoltaic (PV) market-development strategy witnessed a series of policy changes aimed at making distributed-generation PV (DG PV) development an equal priority with large-scale PV development. This article reviews the DG PV policy changes since 2013 and examines their effect on China's domestic DG PV market. Based on a 2014 survey of DG PV market and policy participants, we present cost and time breakdowns for installing DG PV projects in China, and we identify the main barriers to DG PV installation. We also use a cash flow model to determine the relative economic attractiveness of DG PV in several eastern provinces in China. The main factors constraining DG PV deployment in China include financial barriers resulting from the structure of the self-consumption feed-in tariff (FIT), ambivalence about DG PV within grid companies, complicated ownership structures for buildings/rooftops/businesses, and the inherent time lag in policy implementation from the central government to provincial and local governments. We conclude with policy implications and suggestions in the context of DG PV policy changes the Chinese government implemented in September 2014.

Keywords: distributed generation; solar; photovoltaic; soft cost; self consumption; feed-in tariff (FIT) 


\section{Abbreviations}

BNEF Bloomberg New Energy Finance

DG PV Distributed-generation photovoltaics

FIT Feed-in tariff

IRR Internal rate of return

LS PV Large-scale photovoltaics

MHURD Ministry of Housing and Urban-Rural Development

MOF Ministry of Finance

MOST Ministry of Science and Technology

NDRC National Development Reform Commission

NEA National Energy Agency

NREL National Renewable Energy Laboratory

O\&M Operations and maintenance

PV Photovoltaics

RMB Renminbi

SAT State Administration of Taxation

SERC State Electricity Regulatory Commission

SOE State-owned enterprise

VAT Value-added tax 


\section{Introduction}

China has abundant solar energy resources (Liu et al., 2010; Zhang et al., 2009; Li et al., 2007). The estimated technical potential for installing photovoltaics (PV) in China is up to $2,070 \mathrm{GW}$ or 1.7 times the country's cumulative electricity capacity in 2013 (see Table A.1 in the appendix). Beginning in 2009, the Chinese government formulated a series of policies and regulations to encourage domestic PV deployment. The government primarily encouraged the adoption of large-scale PV (LS PV) first, via upfront subsidies of up to $50 \%-70 \%$ under the Golden Sun Demonstration Program and PV Rooftop Subsidy Program (Grau et al., 2012;Sun et al., 2014; Zhang et al., 2012; Zhang and He, 2013). Several disadvantages of providing an upfront subsidy to LS PV, however, became apparent. First, an upfront subsidy provides an incentive to install PV but does not provide a strong incentive for the systems to produce electricity, which resulted in concerns about the installation of low-quality PV projects and cheating the subsidy programs (Zhou, 2012). Second, the central government found the subsidies increasingly difficult to afford. Third, the policy focused on subsidizing LS PV systems, which resulted in installed systems - many in northwest China-being remote from demand centers, creating challenges to the transmission system and the ability to use the generated power. In addition, there is increasing concern about the water required for PV panel cleaning, especially in the dry and sandy northwest area of China (Xie, 2014). 
Distributed-generation PV (DG PV) has several advantages over remote LS PV: (1) typically installed on rooftops, it requires little land, which is at a premium in China; (2) it requires no additional transmission lines, which can reduce installation cost and time; and (3) by being situated close to demand centers, it produces power where needed and thus has reduced electricity losses during transmission (Rigter and Vidican, 2010). Thus the Chinese government has increasingly focused on developing the country's DG PV market since 2013. DG PV projects are defined as "projects with generation on or close to the user site, instantaneously consumed by end users themselves, i.e., self-consumed, and for which redundant power can be grid-connected and the system can be balanced in the grid" (NDRC, 2013), with project sizes smaller than 6 MW (National Grid Company, 2012); the size criterion was expanded to include systems up to $20 \mathrm{MW}$ in 2014 (NEA, 2014a). ${ }^{1}$ In August 2013, the National Development Reform Commission (NDRC) issued a new set of policies to replace the upfront subsidy with a new performance-based national feed-in tariff (FIT) scheme providing $0.42 \mathrm{RMB} / \mathrm{kWh}$ to all generation from DG PV systems for 20 years (Zhang and He, 2013; Sun et al., 2014; Zhang et al., 2014). The new FIT policy for DG PV also distinguishes between self-consumed and excess generated electricity. Self-consumed generation (generation used on site at the time of generation) will be reimbursed at the local retail rate of electricity (in addition to the

\footnotetext{
${ }^{1}$ In September 2014, NDRC expanded the definition of DG PV to include all systems connected to the distribution network up to $20 \mathrm{MW}$ in size, regardless of whether the energy is self-consumed or the system is on a building or ground mounted. When comparing estimates across studies, it is important to note that different studies may use different definitions. For example, other studies have defined DG PV in China to include all rural electrification, communications, and industrial applications and all PV on buildings (IEA-PVPS, 2014).
} 
$0.42 \mathrm{RMB} / \mathrm{kWh}$ ). Excess generation fed into the grid at the time of generation will be purchased by the local grid enterprises at the local wholesale benchmark price for non-sulfur coal-fired generation (around 0.35-0.45 RMB/kWh) (NDRC, 2013).

The DG PV market, however, has not responded rapidly to this new performance-based policy framework. In August 2013, the NDRC and the National Energy Agency (NEA) announced the approval of 1,823 MW of DG PV demonstration projects, of which 793 MW were scheduled for completion by December 31, 2013. All these DG PV projects were funded by the Golden Sun Program rather than the new policy scheme (AECEA, 2014). In 2014, China's government set a target of adding $8 \mathrm{GW}$ of DG PV and $6 \mathrm{GW}$ of LS PV. According to Bloomberg New Energy Finance (BNEF, 2014), about 3.3 GW of PV were connected to the grid in China during the first half of 2014, including roughly $1 \mathrm{GW}$ of DG PV. Many of the DG PV projects installed through the first half of 2014 were approved under the Golden Sun Program, with only a few DG PV projects installed under the new FIT structure.

We obtained detailed information from BNEF's database of 1,207 commissioned or partially commissioned PV projects $(19.6 \mathrm{GW})$ as well as another 305 financing-secured/under-construction PV projects $(8.7 \mathrm{GW})$ and 209 permitted PV projects $(4.7 \mathrm{GW})$ in China. The project information was downloaded from BNEF's database on June 24, 2014. The data, as shown in Table 1 (cumulative installations) 
and Figure1 (annual installations), provide detailed information on the status of PV projects in China, including the average size of projects as well as information about projects in the pipeline. The average size of PV projects installed in China is $16.2 \mathrm{MW}$. The 6-20 MW and 20-100 MW categories account for the majority of systems installed in China to date: $42 \%$ and $47 \%$ of total capacity, respectively. The PV projects of $6 \mathrm{MW}$ or smaller only account for $5 \%$ of the total PV capacity installed to date.

[Table 1.PV Projects Installed, under Construction, or Permitted in China Through

June 24, 2014]

[Fig.1.PV Projects Installed in China Through June 24, 2014]

Confronted with slow market expansion in response to the 2013 policy reforms, in September 2014 the NEA announced Notice on Further Implementation of Policies Relevant to Distributed Photovoltaic Power Generation, which allows DG PV projects to choose to receive a $0.9-1.0 \mathrm{RMB} / \mathrm{kWh}$ FIT by selling all power to the grid, as LS PV projects do, or adopt the previous self-consumption FIT. The change is aimed at easing project-approval difficulties and thus facilitating the realization of the 14-GW installation target for 2014 set by NEA.

A review of the literature indicates that studies of China's PV development have largely centered on China's PV development status, problems, and prospects (Liu et 
al., 2010; Dincer, 2011; Zhao et al., 2011a; Sun et al., 2014) or on the emergence of China's PV manufacturing competitiveness (Zhang and Kumar, 2011; Zhao et al., 2011b; Zhao et al., 2013). Most studies of China's PV deployment focus on the economics of LS PV generation (Zhang et al., 2012), the use of PV in building-integrated applications (Liet al., 2007; Peng et al., 2011), or the use of PV in niche markets (Ling et al., 2002; Byrne et al., 2007; Wang and Qiu, 2009; Zhang and Kumar, 2011). A few studies of China's PV industrial policy present a comprehensive introduction to the country's general PV policy environment (Dincer, 2011; Grau et al., 2012; Huo and Zhang, 2012; Sun et al., 2014; Zhi et al., 2013; Zhi et al., 2014) or the policy incentives for China's entire PV industry (Sun et al., 2014; Zhang et al., 2014). To our knowledge, only a few studies have paid close attention to the emerging DG PV market in China and the intensive policy changes implemented by the Chinese government to stimulate domestic DG PV deployment. For example, Zhang et al. (2014) mention some of the Chinese government's DG PV policy changes during 2013. We are not aware of any studies that specifically explore how DG PV deployment has been developing in China in response to the 2013-2014 policy reforms. This might not be surprising since the DG PV policies and market in China are only recently emerging. However, given the scale of China's goals for DG PV growth, this is an important topic for research.

This article helps fill the gap in the literature by examining the impact of China's PV policy changes since 2013-including barriers that might have slowed market 
response to the policies-while contributing to the literature on DG PV market formation. It also explores the potential effect of the new policy changes China published in September 2014 and identifies opportunities to improve the policy and market conditions for DG PV deployment in China. In the subsequent sections, we discuss the methods and results of our interviews with PV stakeholders in China and our internal rate of return (IRR) analysis by using a cash flow model. We use these approaches to characterize the cost, time, and barriers related to DG PV installation in today's Chinese market as well as the economic return of DG PV under various policy frameworks $^{2}$. The article's final section draws conclusions and makes policy recommendations.

\section{Methods}

To analyze the effect of China's recent PV policies and the potential impact of policies going forward, we conducted interviews with PV stakeholders in China and created a cash flow model to calculate the internal rate of return for Chinese DG PV projects under various policy frameworks. The following subsections describe the methods we used for these analyses.

\subsection{Stakeholder Interviews}

We conducted interviews during July and August 2014-about a year after the August 2013 FIT policy was issued and before the revised September 2014 FIT policy. Our

\footnotetext{
${ }^{2}$ In general, the higher a project's IRR, the more desirable it is to investors and the more likely it is to result in a market response.
} 
subjects included Chinese DG PV installers, project owners, government officials, and representatives of nongovernmental organizations involved in the DG PV industry. Interviews elicited information on the cost structure of DG PV projects, the timeline for completing projects (from customer acquisition to receiving permission to operate the system), and the main barriers in the process of completing projects. We asked interviewees to separate PV costs into hardware costs and soft costs (James et al., 2011; Ardani et al., 2012). Hardware costs can be assessed readily with data from equipment manufacturers and purchasers, and various available indexes exist for quantifying these costs. Quantifying soft costs requires detailed tracking of the time and resources needed to complete the various stages of installing a PV system.

Most general managers interviewed had been engaged in PV deployment and/or research and development for at least the past 3-5 years. Interviews with government officials included key experts at the NDRC involved in designing DG PV market policies and managers at the grid companies involved in implementing the policies. We carried out 17 interviews with 35 individuals (including several group meetings) in eastern areas, including Beijing, Shanghai, Jiangsu, Zhejiang, and Guangdong. We selected eastern cities because they are the main potential areas for installing DG PV. Levels of solar radiation differ across China (Figure 2). The solar resources in the west are much richer than those in the east, while the resources in the north are better than those in the south. However, China's electricity loads are concentrated in the east and south (Zhao et al., 2013). Building PV where the best resources are (in the west) 
requires transporting electricity long distances to China's main electricity-demand centers. There are both technical challenges and economic costs associated with such long-distance transmission.

[Fig.2.Distribution of China's Solar Resource]

We also selected eastern cities because of the regional distribution of PV in China. The LS PV installations mainly have been located in the western provinces, including Gansu, Qinghai, Xinjiang, Ningxia, and Inner Mongolia. At the end of 2013, the top five provinces accounted for $80 \%$ of the cumulative LS PV installations in China. However, DG PV installations were largely distributed in the eastern provinces. The top five provinces for cumulative DG PV installations at the end of 2013 included Zhejiang, Guangdong, Hunan, Jiangsu, and Shandong, which together accounted for $48 \%$ of the cumulative DG PV installations (Table 2). During 2013, Zhejiang, Guangdong, Hebei, Hunan, and Shanghai were the five largest provinces in terms of annual new DG PV installations, accounting for $59 \%$ of the total annual added DG PV.

[Table 2.Top 5 Provinces for Cumulative LS PV and DG PV Installations in China Through the End of 2013]

\subsection{Internal Rate of Return Calculation}

We created a cash flow model to calculate the IRR for DG PV projects and applied it to the industrial/commercial and residential sectors under the 2013 FIT policy 
structure as well as the alternative flat rate structure introduced by the Chinese central government in September 2014; thus we can show the IRR resulting from the 2013 FIT policy and shed light on the IRR that the 2014 FIT policy might bring. The 2013 FIT policy structure provides $0.42 \mathrm{RMB} / \mathrm{kWh}$ to DG PV systems (Sun et al., 2014). Under this policy, self-consumed generation (generation used onsite at the time of generation) is reimbursed at the local retail rate of electricity (in addition to the 0.42 $\mathrm{RMB} / \mathrm{kWh}$ ). Excess generation fed into the grid at the time of generation is purchased by the local grid enterprises at the local wholesale benchmark price for non-sulfur coal-fired generation (NDRC, 2013). However, in September 2014 NEA allowed DG PV projects to choose to receive a $0.9-1.0 \mathrm{RMB} / \mathrm{kWh}$ FIT by selling all power to the grid, as LS PV projects do, or adopt the previous self-consumption FIT.

We applied the model to five cities in the eastern part of China-Beijing, Shanghai, Nanjing, Hangzhou, and Shenzhen — where the economy is highly developed relative to the rest of the country and demand for electricity is high. The focus here is to explore differences in the investment performance resulting from (a) the way DG PV policy is structured, (b) variations in electricity rates across sectors and regions, and (c) variations in solar energy resource across regions.

Calculating the IRR requires a common set of inputs for determining the total 
investment over the system's life and annual after-tax cash flow. ${ }^{3}$ For the total investment required, we include the upfront cost of a DG PV system, an inverter replacement in year 10, and average annual operations and maintenance (O\&M) expenses. We assume a 30-year lifetime for the system. For the after-tax cash flow, we calculate the value of electricity generated by the DG PV system, which depends on the rate and amount of self-consumption (priced at the time-weighted average retail electricity rate), the rate and amount of electricity fed into the grid (either at the local non-sulfur coal-fired power plant benchmark rate or the local LS PV power plant benchmark rate as allowed under the 2014 revised policy), and the FIT rate, as illustrated in equations (1) and (2).

$$
\begin{gathered}
\text { Value }_{\text {self }}=\% \text { self } * E_{P V} *\left(\overline{R_{\text {self }}}+F I T\right) \\
\text { Value }_{\text {nonself }}=(1-\% \text { self }) * E_{P V} *\left(R_{\text {nonself }}+F I T\right)
\end{gathered}
$$

where Value denotes the value of electricity generated by the DG PV system, with subscripts differentiating the types of electricity consumed by the host and fed to the grid; \%self denotes the percentage of self-consumed solar electricity; $E_{P V}$ denotes the annual production of solar electricity; $R$ denotes the electricity rate, with $\overline{R_{\text {self }}}$ for the average retail rate applied on the self-consumed portion of electricity (which will be further explained later) and $R_{\text {nonself }}$ for the rate applied on the non-self-consumed portion; and FIT denotes the FIT rate.

\footnotetext{
${ }^{3}$ IRR is calculated based on its relationship with net present value (NPV) as $N P V=\sum_{n=0}^{N} C_{n} /(1+I R R)^{n}$, where $C_{n}$ is cash flow in year $\mathrm{n}$.
} 
For $E_{P V}$, we first use the National Renewable Energy Laboratory's (NREL's) PVWatts calculator (pvwatts.nrel.gov) to estimate the hourly DG PV system production. We use the default system specification assumptions that include standard module type, fixed roof mount, $20^{\circ}$ tilt, $180^{\circ}$ azimuth, $14 \%$ system losses, $96 \%$ inverter efficiency, and 1.1 DC-to-AC ratio. With these assumptions, different solar energy resources in the five selected cities produce the annual DG PV system production estimates in Table 3.

[Table 3. Annual DG PV Electricity Production Estimates (kWh/kW/year) for the Selected Cities in China]

Electricity rates are another key determinant of the value of electricity generated by DG PV. Substantial variation exists due to different rates for self-consumed versus non-self-consumed solar electricity, residential versus industrial/commercial sectors, alternative incentive policies, and different cities. To illustrate the range of differences in investment performance resulting from these sources of variation, we created four bounding cases that account for the complexity of local electricity rates:

a) $100 \%$ of generation is self-consumed and valued at the appropriate hourly industrial/commercial retail rate of electricity

b) $100 \%$ of generation is self-consumed and valued at the appropriate hourly residential retail rate of electricity 
c) $0 \%$ of generation is self-consumed, and thus $100 \%$ of generation is valued at the local non-sulfur coal-fired power plant benchmark rate (in this case the value of generation is the same for both sectors)

d) $100 \%$ of generation is valued at the local LS PV system rate as allowed under the September 2014 revised policy (again, in this case the value of generation is the same for both sectors).

For the two $100 \%$ self-consumption cases (cases a and b), it is important to account for the fact that different cities in China have different retail electricity rate structures. Among the five cities we evaluated, the most complex rate structure is in Beijing, which has hourly rates for peak, high, flat, and low load periods, in combination with seasonal rates that distinguish summer months from non-summer months. We examined local tariff sheets to model the hourly retail rate structures in each city (for additional details on the hourly rate structures for the industrial/commercial and residential sectors, see Table A.2 and Table A.3 in the appendix).

We use equation (3) to calculate the average value of DG PV electricity in the two $100 \%$ self-consumption cases (cases a and b). We first multiply $E_{P V_{-} h o u r}$, the hourly DG PV system output (as estimated by PVWatts) by $R_{\text {self_hour }}$, the hourly retail rate for each hour in the year (Table A.2 and Table A.3). By summing these values over an entire year, we calculate the total value of DG PV electricity for an entire year, and, by dividing the total value by the total generation, we calculate the average value of DG PV electricity for these two cases (Table 4). 


$$
\overline{R_{\text {self }}}=\frac{\sum_{\text {hour }} E_{P V \_ \text {hour }} * R_{\text {self_hour }}}{\sum_{\text {hour }} E_{P V \_h o u r}}
$$

In the other two cases, we simply set the average value of DG PV electricity at the appropriate benchmark rates: in the $0 \%$ self-consumption case (case c) this is the local non-sulfur coal-fired power plant benchmark rate, and in the $100 \%$ at LS PV rate case (case d) this is the local LS PV system rate. The resulting average values of DG PV electricity in each of these cases for each of the cities are summarized in Table 4. Note that the values shown in Table 4 are in addition to the $0.42 \mathrm{RMB} / \mathrm{kWh}$ FIT payments system owners receive.

[Table 4.Average Value of DG PV Electricity $(\mathrm{RMB} / \mathrm{kWh})$ in the Four Bounding Cases]

We also account for taxes. According to MOF and SAT (2013), revenue from the 0.42 $\mathrm{RMB} / \mathrm{kWh}$ FIT and self-consumed electricity is exempted from value-added tax (VAT). Thus cases a and b have a $0 \%$ tax rate. However, electricity sold by a DG PV project to the grid companies is subject to VAT but with a $50 \%$ rebate, resulting in a tax rate of $7.3 \%$ applied to the values shown in Table 4 for cases $\mathrm{c}$ and $\mathrm{d}$.

Table 5 summarizes the assumptions in our economic analysis. The electricity rate escalator is assumed to be $1.0 \%$ per year for both the retail rate of electricity and the non-sulfur coal-fired power plant benchmark rate. In setting this escalation rate, we 
examined historical trends in retail and wholesale electricity rates in China between 2006 and 2014. We found that the average historical escalation rates for these two variables during this period were both approximately $1 \%$. The values chosen for the rest of the assumptions are based on our interviews in China with a range of installers and market participants. The assumptions in Table 5 are applied across the four cases.

[Table 5.Summary of Economic Assumptions]

\section{Results and Discussion}

This section first provides results and discussion for information gathered through our interviews, including the estimated cost breakdown for installing a DG PV system (Section 3.1), a timeline for the various stages of installing a system (Section 3.2), and the major barriers to expanding DG PV in China (Section 3.3). Section 3.4 presents results and discussion for our cash flow modeling.

\subsection{Cost Breakdown for Installing a DG PV System}

Our interviewees said the installed system cost for a multi-MW (1-10 MW) rooftop installation is $7-10 \mathrm{RMB} / \mathrm{W}{ }^{4}$ However, some installers (in particular on the lower end of the cost range) were referring to the "overnight capital costs" of installing a system, not the all-in cost of having a viable business. Thus the lower estimates likely

\footnotetext{
${ }^{4}$ While the National Grid Company set a 6-MW cap on DG PV system size, installations up to 10 MW are often spread over multiple rooftops with separate grid-interconnections to stay under this cap. Thus, in general, interviewees referred to systems in the 1-10 MW size as being distributed-generation systems.
} 
did not include all costs. Our best estimate of the installed system cost from a viable business perspective (accounting for profit, business development, etc.) is in the $9-10$ $\mathrm{RMB} / \mathrm{W}$ range. In our economic analysis (Section 3.4), $9 \mathrm{RMB} / \mathrm{W}$ is our assumed installed-system cost.

The typical cost breakdown for a multi-MW DG PV system is $70 \%$ hardware and $30 \%$ soft costs (Table 6). Hardware costs account for 5-7 RMB/W, and soft costs account for $2-3 \mathrm{RMB} / \mathrm{W}$. Among the soft costs, profit margin is the biggest cost component at 0.7-1 RMB/W. Labor costs are 0.4-0.8 RMB/W, customer-acquisition costs are $0.3-$ $0.5 \mathrm{RMB} / \mathrm{W}$, and other costs (design, etc.) are 0.6-0.7 RMB/W.

[Table 6.Cost Breakdown for Installing a 1-10 MW DG PV System in China during $2014(\mathrm{RMB} / \mathrm{W})]$

\subsection{Timeline for Installing a DG PV System}

Project timelines vary significantly from project to project (due to differences in project details) and across provinces (due to differences in local policies and processes). Table 7 presents a detailed breakdown of the timeline for installing a DG PV project, including the range of possible times required for each step. The timeline data in the table were collected from 12 DG PV project developers that we interviewed in the summer of 2014 in China. The column named Shortest refers to the shortest time in which the PV project developers claimed to complete each phase in a 
typical DG PV project. The column named Longest refers to the longest time in which the PV project developers claimed to complete each phase. The column named Average refers to the average time in which all $12 \mathrm{PV}$ project developers claimed to complete each phase. A number of the phases can overlap or occur simultaneously. For example, system design, permitting, and financing can all happen at the same time. Thus the individual components cannot be summed to provide the total time range.

Completing a multi-MW DG PV project may require 3 months to more than 1 year (Table 7). The customer-acquisition phase varies the most and can take the most time at $0.5-6$ months. Navigating the permitting process takes $1-4+$ months. Many projects drop out in the customer-acquisition and permitting phases if issues cannot be resolved quickly, thus streamlining these processes is important for market development. The inspection and interconnection processes take less time, from $0.5-2$ months.

[Table 7.Timeline for Installing a 1-10 MW DG PV System in China during 2014]

\subsection{Main Barriers for DG PV Projects in China}

This section discusses the main barriers to DG PV expansion, which can be grouped into six categories: customer acquisition, contracting, financing, permitting and grid connection from the utility, permitting and subsidy application from the government, and installation. We discuss each of these barriers in turn. 


\subsubsection{Barriers in Customer Acquisition}

The main customers for DG PV installations are industrial or commercial firms, rather than homes. Customer acquisition entails a number of barriers. First, identifying suitable rooftops is a significant challenge and can take considerable time. Assessing structural suitability is critical. For new buildings this is straightforward, i.e., documentation on a roof's structural capabilities is readily available and can be presented to the local certifying board. For older buildings, however, this type of documentation is often not available, so the structural suitability of the roof for PV must be assessed. For many rooftops in China, the weight loading capacity is limited. For example, for some rooftops in industrial parks, the limit is less than $10 \mathrm{~kg} / \mathrm{m}^{2}$, but crystalline silicon glass PV modules (today's dominant module type) typically weigh around $11-12 \mathrm{~kg} / \mathrm{m}^{2} .5$ Racking and mounting hardware can double the system weight. Strategies for reducing the weight include: (a) reducing system size and spreading the weight more evenly; (b) strengthening the rooftop, which could add $5 \mathrm{RMB} / \mathrm{m}^{2}$, equivalent to a $0.4 \%$ increase of the system cost; and (c) using lightweight modules (thin-film or ultra-thin modules), which are currently significantly more expensive.

Another hurdle is the short lifespan of many rooftops in China, which are often

\footnotetext{
${ }^{5}$ For example a standard monocrystalline silicon framed glass module produced by Yingli Solar weighs $11.7 \mathrm{~kg} / \mathrm{m}^{2}$ (http://www.yinglisolar.com/assets/uploads/products/downloads/YGE_60_Cell_Series_EN.pdf, accessed 8/31/14). A standard monocrystalline silicon framed glass module produced by JA Solar weighs $11.1-11.4 \mathrm{~kg} / \mathrm{m} 2$, and a standard polycrystalline silicon framed glass module produced by JA Solar weighs 11.1-11.6 kg/m2(http://www.jasolar.com/webroot/products/modules.php, accessed 8/31/14).
} 
designed to last only $10-15$ years, while the DG PV lifespan is $20-30$ years. This mismatch can result in investors or customers requiring a higher return on investment. The relatively short lifespan of Chinese firms (5-7 years) can have a similar effect.

The residential market is particularly challenging in China. The residential electricity rate is much lower than commercial and industrial electricity rates, making the self-consumption FIT less attractive for residential systems. In addition, in urban areas people mainly live in condos or apartments, rather than single-family homes. Even in rural areas people are encouraged to move into high-rise buildings. As a result, large commercial or industrial roofs have been the main targets for DG PV in China.

\subsubsection{Barriers in Contracting}

Negotiating a DG PV contract for a commercial facility, factory, or industrial park is often hindered by the facilities' complicated ownership structures, potentially involving building owners, a property management company, the electricity endusers, and other stakeholders. Negotiating with multiple parties for roof space and electricity sales can be time consuming and difficult, especially with China's limited contracting standards. Complications also arise due to the principal-agent dilemma when contracting between a property management company and electricity endusers. Thus, there is urgent need for standardization of DG PV contracting processes.

China has relatively weak legal and institutional mechanisms for enforcing contracts 
and contract payments. This hinders financing, in particular for systems under the self-consumption FIT scheme: banks and investors are not confident of consistent self-consumption payments from the building owner or occupier. In contrast, for LS PV projects, all FIT payments are paid directly by the grid companies, which provides a secure "bankable" stream of payment. In our interviews, some installers emphasized the risk that electricity endusers will not pay for the "self-consumed" electricity. Securing financing would be easier if all payments for DG PV electricity came from the grid companies, which have billing systems and can disconnect customers who do not pay. PV system installers do not have these advantages, and this is a serious barrier to securing financing.

The weak contracting environment also can confront PV installers with changes in the building owner's requirements after signing a contract. For example, after a PV project has started to operate, the building owner might insist on payments for profit sharing or renting the roof.

\subsubsection{Barriers in Financing}

Financing has been the biggest barrier to DG PV under the self-consumption FIT structure issued by the NDRC in August 2013 (Zhang and He, 2013; Sun et al., 2014; Zhang et al., 2014).This self-consumption FIT structure has created uncertainty surrounding payments for DG PV projects. First, determining the level of self-consumption a priori is difficult. Markets fluctuate with seasonal and weekly 
demand variations. Second, it is difficult to predict system performance a priori, owing to a lack of solar resource data and experience with issues like soiling, O\&M, and system degradation. Third, companies and factories in China tend to turn over every few years. If a company, especially the end consumer, goes out of business and self-consumption drops, then the developer will get the lower electricity rate. Fourth, there are policy uncertainties around DG PV projects, including the source of subsidy funds and the stability of subsidy policies. Fifth, banks are concerned about PV depreciating rapidly, which could be an issue if the asset must be transferred to the bank. Finally, the lack of standard insurance products for system performance discourages banks from investing in DG PV projects.

Banks are the main financial providers to China's PV industry. However, through mid-2014, Chinese banks preferred to invest in PV manufacturing rather than deployment. When investing in PV deployment, banks have been more willing to invest in larger (>10MW) LS PV projects and to lend to state-owned enterprises (SOEs) and multinationals rather than smaller local firms. In our interviews, smaller DG PV installers said they are often disadvantaged by paying higher interest rates for loans. The average loan interest rate is $10 \%$ in China, but the government requires banks to provide $7 \%$ loans to green development, including PV projects. Yet some of the smaller installers we spoke with said they can only get loans with interest rates of 10\%-15\%. Some DG PV developers can get financial support from leasing companies, but leasing companies typically require a $13 \%$ rate of return. Offshore 
funds typically require a $4 \%-5 \%$ rate of return, but they are reluctant to invest in China's DG PV market owing to uncertain returns and policy instability. To improve the access of small and middle sized PV developers to capital, the Chinese government could help to establish specific private or public PV focused funds. The Chinese government could also implement some preferential tax schemes to help small and middle sized PV developers acquire financial resources.

\subsubsection{Grid Company Barriers to Permitting and Grid Connection}

China's Renewable Energy Law in 2005 and the modification of this law in 2009 required grid companies to provide grid connection to renewable energy projects. In March 2012, Interim Measures for Additional Subsidy Funds of Renewable Energy Tariff issued by the Ministry of Finance (MOF), NDRC, and NEA stated that grid update costs for renewable energy projects on grid companies' side would be compensated by $0.01 \mathrm{RMB} / \mathrm{kWh}$ for projects within $50 \mathrm{~km}$ of the existing grid, 0.02 $\mathrm{RMB} / \mathrm{kWh}$ for projects within $50-100 \mathrm{~km}$ of the existing grid, and $0.03 \mathrm{RMB} / \mathrm{kWh}$ for projects further than $100 \mathrm{~km}$ from the grid. In response to this subsidy policy and political pressure from the central government, the National Grid Company, China's largest state-owned grid company, announced that, starting on November 1, 2012, it would provide free connection services for DG PV electricity producers located close to customers. However, the National Grid Company set a 6-MW cap for DG PV projects, meaning that only DG PV projects less than $6 \mathrm{MW}$ each would be provided with free grid-connection service. These services provided by the National Grid 
Company cover technological assistance, including equipment testing and integration plan development, among other services (Zhang and He, 2013). This set of policies from the National Grid Company not only guarantees that DG PV systems can connect to the grid, but also significantly reduces the cost of DG PV projects for installers by waiving both service fees and engineering fees (Table 8). In 2013 and 2014, the National Grid Company, as well as the Southern Grid Company, released several additional policies to facilitate grid-connection services for DG PV projects.

[Table 8. DG PV Grid-Connection Services Provided by the National Grid Company]

Views, however, on the attitude of the grid companies towards DG PV projects varied widely in our survey. Some interviewees said permitting and interconnection are straightforward, relatively smooth, and aligned with the supportive grid-connection polices published by the grid companies. Others, however, said the National Grid Company has been dragging its feet, because it incurs the cost of integration and loses revenue due to DG PV.

One barrier is that DG PV policy implementation and integration are through the grid companies' management networks. Even though the National Grid and Southern Grid Companies are somewhat hierarchical SOEs, policy implementation from the central level to the provincial and local grid companies takes time. Local grid companies are often more resistant to DG PV development, because DG PV reduces their electricity revenue and increases administrative costs. While this was the general trend, we 
observed considerable variation across and within provinces. The local grid companies in Jiangsu and Zhejiang provinces are more supportive of DG PV compared with those in Beijing and Guangdong. A possible reason is that Jiangsu and Zhejiang, unlike Beijing and Guangdong, are home to a number of large PV module manufacturing facilities; thus, when the local governments stimulate local PV deployment in these two provinces, they support their local PV manufacturing and employment as well.

Lack of standards for connecting DG PV to the grid at different voltages is another potential barrier. Few regulations and instructions in China show how to connect DG PV to the grid. In addition, there is a lack of planning for distributed power generation at the distribution and transmission levels. The integration challenges are exacerbated because investments in grid construction lag behind investments in capacity expansion. From 2002 to 2007, investment in power generation increased from 74.7 billion RMB to 322.6 billion RMB at an average annual rate of $28 \%$. At the same time, the grid investment only increased at an annual rate of $9 \%$, from 157.8 billion RMB to 245.1 billion RMB (Zhao et al., 2011b). As documented for wind-power installations, inadequate grid investment can lead to stranded capital investments (Li et al., 2013).

\subsubsection{Government Barriers to Permitting and Subsidy Application}

The Chinese government has been promoting DG PV market development more aggressively and using performance-based incentives rather than upfront subsidies 
since 2013. In January 2013, the State Council issued the $12^{\text {th }}$ Five-Year Plan of Energy Development, which put equal emphasis on LS PV and DG PV (State Council 2013; Zhang et al., 2014). Later, China's $12^{\text {th }}$ Five-Year Plan for Solar Energy Development targeted $10 \mathrm{GW}$ of installed DG PV by the end of 2015 and aimed to establish 100 distributed-generation renewable deployment and demonstration cities (NEA, 2014b). A series of supporting policies for DG PV deployment was published by the NDRC, NEA, MOF, Ministry of Science and Technology (MOST), China Development Bank, and state-owned National Grid Company (for a full list of policies, see Table A.4 in the appendix).

Some provincial/local governments have also implemented additional incentives and policies to promote DG PV market development. For example, in 2013, the Jiangxi provincial government provided another $0.2 \mathrm{RMB} / \mathrm{kWh}$ to local PV installations. The local government also launched its provincial 10,000-roof demonstration program by providing $4 \mathrm{RMB} / \mathrm{W}$ for the first stage of the program and $3 \mathrm{RMB} / \mathrm{W}$ for the second stage (for additional details, see Table A.5 in the appendix). At the local level, incentives are often aimed at maintaining local manufacturing employment. This has been especially true during the past couple of years, i.e., during a period of overcapacity in global PV production (Grau et al., 2012).

Government time lags in policy implementation are a crucial barrier to DG PV development. The central government's DG PV policies proceed slowly through 
dissemination by provincial and local governments. When the NDRC published its DG PV policy in August 2013, it expected provincial governments to act quickly, but, by the end of July 2014, only 13 provinces had issued corresponding policies. Owing to limited local understanding of DG PV, some local governments still do not know how to implement the DG PV policy.

Government permitting is a key step in the DG PV process. In the past, PV projects had to get NEA permission before installation. Beginning in November 2013, NEA tried to shorten the process by requiring only a "report" to NEA. It required the provincial governments to elaborate their policy for the reporting process. However, because there is no standardized DG PV process for local governments, the time required to get local government permission can vary from a couple of weeks to 4-6 months.

In the subsidy process, the biggest public policy barrier is uncertainty surrounding the self-consumption FIT structure. PV installers are uncertain about the flow of the 0.42 $\mathrm{RMB} / \mathrm{kWh}$ FIT payment as well as the energy payments from the customer and for electricity fed to the grid. When the policy was promulgated in 2013, it was unclear if the grid companies would be responsible for these payments. Additionally, it was unclear how individuals (non-commercial entities) would be able to obtain payments for the full non-sulfur coal-fired benchmark price as well as the subsidy of RMB 0.42/ $\mathrm{kWh}$. The utility requires a receipt to issue the non-sulfur coal-fired benchmark price 
payment, but individuals are not legally empowered to issue receipts-only businesses can issue receipts. To solve this problem, the State Administration of Taxation issued a new policy in July 2014 requiring grid companies to provide these receipts.

\subsubsection{Barriers to Installation}

In terms of both mechanical and electrical installation, labor availability was not a significant issue in the interviews. However, labor cost has been increasing significantly in China during the last decade, and there was concern about this making labor cost a more significant burden in the future.

In addition, a lack of standards and potential quality issues related to PV modules are often a concern for DG PV project developers. For example, although the module degradation rate is a key quality metric, China has not published any national or industrial standards for this rate. As a result, modules installed in China have a degradation rate higher than the typical rate in more developed markets, which prevents many Chinese DG PV projects from achieving their electricity-generation goals. This uncertain quality also hinders financing and market expansion of DG PV projects in China.

\subsection{Internal Rate of Return Results}

In addition to the variety of barriers discussed above, uncertainty surrounding the real 
value of a DG PV system was mentioned repeatedly by our interviewees. Our IRR results quantify the extent to which the value of DG PV is affected by the share of self-consumption, installation in the residential sector versus industrial/commercial sector, and use of the 2013 FIT policy versus the 2014 incentive policy. Many other uncertainties would also affect IRR, such as actual system performance based on module quality and installation, the risk of factory closure where systems are installed, and the risk of FIT payments and payments for electricity fed to the grid going unpaid at the local level. However, we focus on the effects of government incentive policy and assume fixed values for other uncertainties.

Figure 3 shows the results of our IRR calculations. On the x-axis, five groups of bars represent the five cities evaluated. In Beijing, for example, the first three bars from the left demonstrate the investment potential of DG PV projects under the FIT policy structure. The first bar denotes the scenario of industrial/commercial DG PV with $100 \%$ self-consumption, and the second bar is for residential DG PV with 100\% self-consumption. This comparison clearly indicates that the structure of the self-consumption FIT significantly favors industrial/commercial projects over residential projects. This is driven primarily by the fact that average industrial/commercial electricity rates are higher than residential electricity rates in most of China. The difference in IRR between the industrial/commercial sector and the residential sector is most pronounced in Beijing, with smaller but still substantial differences for Shanghai, Hangzhou, and Nanjing. Only in Shenzhen is the difference 
between retail electricity rates for the industrial/commercial sector and residential sector relatively small.

[Fig.3.Internal Rate of Return across the Four Bounding Cases and Five Cities]

The third bar in Figure 3 represents DG PV with 0\% self-consumption, which means all the generated electricity is sold to grid companies. The resulting IRRs are significantly lower than the first two bars (representing 100\% self-consumption) in all of the cities examined. This result clearly illustrates that, without a high fraction of self-consumption, a project's IRR would drop substantially under the self-consumption FIT structure. The first and third bars are the upper and lower bounds of the IRR for an industrial/commercial project, whereas the second and third bars are the upper and lower bounds for a residential project. Figure 3 illustrates the presence and magnitude of uncertainty in IRRs for DG PV projects under the self-consumption FIT and helps to explain why banks and other investors were so reluctant to invest in DG PV projects under this incentive structure.

The fourth bar represents the IRR for the DG PV when $100 \%$ of generation is valued at the local LS PV system rate as allowed under the September 2014 revised policy. This case can be viewed as providing a new guaranteed minimum IRR to DG PV projects. For industrial/commercial projects, in four of the cities (Shanghai, Hangzhou, Nanjing, and Shenzhen) there is a relatively small difference between the IRRs under the $100 \%$ self-consumption case and the LS PV rate case, which would likely make 
the new option preferable because it eliminates the investment uncertainty linked with self-consumption. In Beijing there is still a substantial difference between the industrial/commercial IRRs under the $100 \%$ self-consumption case and the LS PV case; however, by providing a much higher minimum IRR that a project could switch to if self-consumption drops unexpectedly, the new policy reduces much of the investment uncertainty linked with self-consumption in this city as well. For residential projects, the option to value $100 \%$ of generation at the local LS PV system rate offers an IRR higher than the $100 \%$ self-consumption case in all five cities. Taken together, the results show that the new policy provides additional support to both industrial/commercial and residential DG PV projects, and it helps reduce the uncertainty in returns associated with the self-consumption FIT structure.

\section{Conclusions and Policy Implications}

Beginning in 2013, China implemented policies to promote DG PV deployment, including a new self-consumption FIT structure. However, DG PV installations totaled only $0.8 \mathrm{GW}$ in 2013 and less than $1 \mathrm{GW}$ in the first half of 2014 . The contrast between strong DG PV policies and slow deployment prompted us to explore the constraints in the Chinese market and identify opportunities for improving the policy and market conditions for DG PV deployment.

We find that cost is not a significant barrier to DG PV development in China. The typical cost of a multi-MW DG PV system in 2014 is $7-10 \mathrm{RMB} / \mathrm{W}: 70 \%$ of this as 
hardware costs and $30 \%$ as soft costs. Even though there are uncertainties in our assessment, the soft costs of DG PV installation in China appear to be very low compared to costs in other countries. For example, soft costs in the United States in 2012 amounted to $\$ 3.25 / \mathrm{W}$ (equivalent to $20.5 \mathrm{RMB} / \mathrm{W}$ ), accounting for $70 \%$ of the total cost (Ardani et al., 2012), and soft costs in Japan in the first half of 2013 were $\$ 1.4 / \mathrm{W}$ (equivalent to $8.8 \mathrm{RMB} / \mathrm{W}$ ), accounting for $50 \%$ of the total cost (Friedman et al., 2014). The low cost of Chinese DG PV suggests there must be other key market and policy constraints.

Our interviews and analysis indicate that the most crucial barriers to DG PV are uncertainty about project returns and resulting difficulty securing project financing under the self-consumption FIT structure. Under this structure, IRRs for industrial/commercial DG PV projects can reach $14 \%-23 \%$ if all the generated electricity is self-consumed for our five selected cities; however, with zero self-consumption, the IRRs drop to $6 \%-7 \%$. In setting up the self-consumption FIT structure, the NDRC assumed that $80 \%$ of DG PV electricity would be self-consumed, but electricity demand fluctuates significantly on a seasonal and weekly basis, and firms turn over rapidly in China. Thus it is almost impossible for developers of DG PV projects to persuade financial agencies to invest without a stable and profitable IRR. According to our interviews, the typical IRR required by DG PV project developers in China is around $10 \%-14 \%$. The new policy framework published in September 2014 represents a significant step forward in reducing the uncertainty of 
DG PV IRRs. Under this framework, IRRs can be at least $14 \%-16 \%$ if the project opts for the LS PV project FIT payment scheme. If implemented effectively, this new option would provide a more bankable payment stream for projects at a higher minimum IRR, which may stimulate the rapid expansion of DG PV.

Other key market and policy barriers to DG PV include complicated ownership structures and the principal-agent and profit-sharing problems behind them, which make contract negotiations complex and time consuming. Another barrier is potential resistance from the grid companies as the DG PV market scales up, because all the costs related to grid upgrades, administrative fees, and reduced revenue are borne by the grid companies. Grid companies, especially the local grid companies, have delayed DG PV projects. There are also significant time lags between policy creation by the central government and implementation by provincial and local governments. In addition, frequent DG PV policy changes create market uncertainty and thus hinder deployment.

While the new policy framework published in September 2014 represents an important step forward, if the Chinese government wants to stimulate DG PV deployment further, we recommend that the following additional policies be pursued in the near term:

- Increase education and training activities related to PV or DG PV projects to increase the population's understanding of PV technology and deployment. 
- Collect and make publically available regional and local solar and rooftop resource information based on detailed scientific data gathering and assessment for the whole country.

- Encourage the development and adoption of clear contracting rules related to profit sharing among multiple stakeholders involved in DG PV projects, including rooftop owners and end users.

- Help local governments, which lag behind in policy implementation, implement existing DG PV policies as soon as possible. Also help local governments develop and publish their own DG PV guidelines and supportive policies.

A number of additional policies could be pursued in the longer term, including the following:

- Promote the broad adoption of more standardized contracting processes to streamline the negotiation of DG PV projects, shorten the time consumed in the contracting process, and reduce the number of projects dropped during this phase of development.

- Develop a cost-sharing mechanism between grid companies and DG PV developers to limit the cost of grid upgrades. For example, the government could set a maximum threshold for free upgrades (in $\mathrm{RMB} / \mathrm{W}$ ) to the distribution network. If a system required higher-cost upgrades, the project developer/system owner could pay for them or redesign their system to reduce the impact on the distribution network (reduce system size, use smarter 
inverters or controls, etc.).

- Engage local governments over the longer-term to implement DG PV policies and shorten time lags in policy implementation. Strategies local governments could pursue to encourage DG PV market development include identifying suitable rooftops in conjunction with the grid companies- to ensure structural integrity and limited distribution-system impacts-and encouraging cooperation among the multiple actors involved in the contracting, financing, and interconnection processes, with the goal of creating standard contracts and streamlined processes.

- Maintain a stable policy framework for China's DG PV market. Stable policy expectations and market anticipation are crucial to attracting more private investment to the DG PV market place.

\section{Acknowledgements}

This research was supported by the U.S. Department of Energy under contract number DE-AC36-08GO28308 (with NREL) and the Ministry of Science and Technology under contract number 2011AA05A304 (with Tsinghua University). We wish to thank Jingyu Wang, Suxiu Li, Xingli Sun, Meng Wang, Kunkun Miao, and Huajian Long for their assistance in carrying out our field work in China. We also appreciate the planning support and assistance of Barry Friedman (formerly with NREL) and Penny Storey (Tufts University), and the editorial support of Jarett Zuboy (independent 
contractor). Finally, we are grateful to the 35 people we interviewed in China as part of this research for their willingness to share insights. All remaining errors are the sole responsibility of the authors.

\section{References}

[1] AECEA (Asia Europe Clean Energy (Solar) Advisory Co. Ltd), 2014. Jan 2014-Briefing-Paper-China Solar PV Development. Accessed December 23, 2014: http://www.frankhaugwitz.info/mediapool/134/1345433/data/2014_02_18_China_Briefing_P aper_Solar_Market_Development_Frank_Haugwitz_AECEA.pdf.

[2] Ardani, K., Barbose, G., Margolis, R., Wiser, R., Feldman, D., Ong, S., 2012. Benchmarking Non-Hardware Balance of System (Soft) Costs for U.S. Photovoltaic Systems Using a Data-Driven Analysis from PV Installer Survey Results. NREL/TP-7A20-56806. National Renewable Energy Laboratory, Golden, CO.

[3] Beijing Municipal Commission of Development and Reform, 2014. Electricity Rate (in Chinese). Accessed August 28, 2014: http://www.bjpc.gov.cn/ywpd/wjgl/cx/jz/201208/t3884351.htm.

[4] BNEF (Bloomberg New Energy Finance), 2014. H2 2014 China Market Outlook. Bloomberg New Energy Finance, New York.

[5] Byrne, J., Zhou, A., Shen, B., Hughes, K., 2007. Evaluating the potential of small-scale renewable energy options to meet rural livelihoods needs: A GIS- and lifecycle cost-based assessment of Western China's options. Energy Policy 35(8), 4391-4401.

[6] China Cell Website, 2014. A Summary of Regional PV Policy in China from 2013 to 2014 (in Chinese). Accessed September 2, 2014: http://www.dc168.cn/News/Information_Content.asp?D_ID=22768.

[7] Dincer, F., 2011. The analysis on photovoltaic electricity generation status, potential and policies of the leading countries in solar energy. Renewable and Sustainable Energy Reviews 15(1), 713-720.

[8] Friedman, B., Margolis, R., Seel, J., 2014. Comparing Photovoltaic (PV) Costs and Deployment Drivers in the Japanese and U.S. Residential and Commercial Markets. NREL/TP-6A20-60360. National Renewable Energy Laboratory, Golden, CO.

[9] Grau, T., Huo, M.L., Neuhoff, K., 2012. Survey of photovoltaic industry and policy in 
Germany and China. Energy Policy 51, 20-37.

[10] Hangzhou Municipal Bureau of Price, 2012. Policy on new residential tiered electricity rates (in Chinese). Accessed August 28, 2014: http://www.hzjg.gov.cn/zcjda/9138.htm.

[11] He, T., 2007. Our Province Power Grid Began to Collect Reserve Capacity Fees for Power Plants Self-owned by Facilities (in Chinese). Accessed September, 24, 2014: http://www.sxdaily.com.cn/data/jjxwdd/03/20070505_9931232_1.htm.

[12] He, F. and Liu, S., 2014. DG Policy to trigger a peak season for installation. New York, NY: Goldman Saches Group, Inc.

[13] Huo, M., Zhang, D.W., 2012. Lessons from photovoltaic policies in China for future development. Energy Policy 51, 38-45.

[14] IEA-PVPS, 2014. Photovoltaic Power Systems Program Annual Report 2013. Accessed July 3, 2014: file:///C:/Users/Fang\%20Zhang/Downloads/IEA-PVPS-AR2013_web.pdf.

[15] James, T., Goodrich, A., Woodhouse, M., Margolis, R., Ong, S., 2011. Building-Integrated Photovoltaics (BIPV) in the Residential Sector: An Analysis of Installed Rooftop System Prices. NREL/TP-6A20-53103. National Renewable Energy Laboratory, Golden, CO.

[16] Li, J.F, Liu, Y., Wang, S.C., 2009. China's PV Industry Development 2008 Annual Report (in Chinese). Accessed May 20, 2014: http://wenku.baidu.com/link?url=cG-FHwWRjDqpqGUbmdHtVp0OXP_crMgw2WtKxoPrN jp45OyXhHEfLvyG03o9aPI3uz2d3ddKS1n0BtfqoNXqH7CF679cytLwFeOH6O0HfCe.

[17] Li, J.F., Cai, F.B., Qiao, L.M., Gao, H., Wang, J.X., Tang, W.Q., Peng, P., Li, X.Q., 2013. 2013 Annual Review and Outlook on China Wind Power (in Chinese). Accessed May 25, 2014: http://doc.mbalib.com/view/6e1adfea3bd1365a058b2918e9b678fa.html.

[18] Li, Y.Q., Li, Y.Q., 2012. Response to Premier Wen's Instructions, Support DG PV by Sacrificing Profit, DF Daily. Accessed July 25, 2014: http://finance.ifeng.com/news/macro/20121027/7214668.shtml.

[19] Li, Z.S., Zhang, G.Q., Li, D.M., Zhou, J., Li, L.J., Li, L.X., 2007. Application and development of solar energy in building industry and its prospects in China. Energy Policy 35, $4121-2127$.

[20] Light Energy Publisher, 2014. A Summary of Regional PV Subsidy Policy in China (in Chinese). Accessed September 1, 2014: http://www.shinergy.org/201402/10/1216.html.

[21] Ling, S.J., Twidell, J., Boardman, B., 2002. Household photovoltaic market in Xining, Qinghai province, China: the role of local PV business. Solar Energy 73(4), 227-240.

[22] Liu, S.S., Qian, M.J., Liu, H.M., 2012. Release Soft and Help PV--National Grid's Notice (in Chinese). Accessed April 23, 2014: http://www.solarbe.com/topnews/201211/06/64.html. 
[23] Liu, L.Q., Wang, Z.X., Zhang, H.Q., Xue, Y.C., 2010. Solar energy development in China-A review. Renewable and Sustainable Energy Reviews 14, 301-311.

[24] Meng, W., 2011. Beijing to adjust non-residential summer electricity peak pricing periods from July, 2011 (in Chinese). Accessed August 28, 2014: http://www.gov.cn/fwxx/sh/2011-07/01/content_1897458.htm.

[25] MOF and SAT (State Administration of Taxation), 2013. Notice on the Policy of Solar PV Electricity Value Added Tax (in Chinese).

[26] Nanjing Economic Commission, 2012. Notice on Jiangsu province retail electricity rates (in Chinese). Accessed August 28, 2014: http://www.njec.gov.cn/dlny/4906.jhtml.

[27] National Grid Company, 2012. Notice on Providing Grid Connection Service for DG PV Projects (Provisional) (in Chinese).

[28] National Grid Company, 2013. Opinions on Grid-Connection Service Prepared for the DG PV Development (in Chinese).

[29] NDRC (National Development Reform Commission), 2013. Notice about Playing the Role of the Price Lever to Promote the Healthy Development of Photovoltaic Industry (in Chinese).

[30] NEA (National Energy Agency), 2014a. Notice on Further Implementation of Policies Relevant to Distributed Photovoltaic Power Generation (in Chinese).

[31] NEA, 2014b. The 12th Five Year Plan for Solar Energy Development (in Chinese).

[32] OFweek, 2014. The PV Generation Subsidies in Zhejiang Province (in Chinese). Accessed September 2, 2014: http://solar.ofweek.com/2014-01/ART-260009-8480-28767333.html.

[33] Peng, C.H., Huang, Y., Wu, Z.S., 2011. Building-integrated photovoltaics (BIPV) in architectural design in China. Energy Build 43, 3592-3598.

[34] PV-Tech, 2014. China's Official PV Policy Summary from 2012 to 2014 (in Chinese). Accessed September 1, 2014: http://www.nandudu.com/articles/8956.

[35] Renewable Energy Information Management Center, 2014. New added capacity of PV generation in China in 2013 (in Chinese). Accessed Oct 14, 2014: http://www.renewable.org.cn/shownews.jsp?id=8ad6808845a04ce60145af73693e0003\&funi $\mathrm{d}=95 \&$ modulid $=7 \&$ type $=$ content.

[36] Rigter, J., Vidican, G., 2010. Cost and optimal feed-in tariff for small scale photovoltaic systems in China. Energy Policy 38, 6989-7000.

[37] Shanghai Municipal Commission of Economy and Informatization, 2012. Shanghai local electricity rates (in Chinese): http://www.sheitc.gov.cn/dfjf/637315.htm.

[38] Shenzhen Online, 2012. Shenzhen tiered electricity rates. Accessed August 1, 2014 : http://life.szonline.net/pg/by/a3087_2.html. 
[39] State Council, 2013. The 12th Five Year Plan of Energy Development (in Chinese).

[40] Sun, H.S., Zhi, Q., Wang, Y.B., Yao, Q., Su, J., 2014. China's solar photovoltaic industry development: the status quo, problems and approaches. Applied Energy 118, 221-230.

[41] Wang, Q., Qiu, H.N., 2009. Situation and outlook of solar energy utilization in Tibet, China. Renewable and Sustainable Energy Reviews 13, 2181-2186.

[42] Wu, X.X., 2014. The key to DG PV is firms' innovation (in Chinese). Accessed September2, 2014: http://www.cs.com.cn/xwzx/cj/201408/t20140818_4484502.html.

[43] Xie, D., 2014. Solar power stations have encountered "water crisis" (in Chinese). Southern Weekly. Accessed December 23, 2014: http://www.infzm.com/content/103427.

[44] Zhang, S.F., Andrew-Speed, P., Ji, M.Y., 2014. The erratic path of the low-carbon transition in China: Evolution of solar PV policy. Energy Policy 67, 903-912.

[45] Zhang, D., Chai, Q.M., Zhang, X.L., He, J.K., Li, Y., Dong, X.F., Wu, S., 2012.Economical assessment of large-scale photovoltaic power development in China. Energy 40, 370-375.

[46] Zhang, S., He, Y.X., 2013.Analysis on the development and policy of solar PV power in China. Renewable and Sustainable Energy Reviews 21, 393-401.

[47] Zhang, X.L., Kumar, A., 2011. Evaluating renewable energy-based rural electrification program in western China: Emerging problems and possible scenarios. Renewable and Sustainable Energy Reviews 15, 773-779.

[48] Zhang, P. D., Yang, Y.L., Zheng, Y.H., Wang, L.S., Li, X.R., 2009. Opportunities and challenges for renewable energy policy in China. Renewable and Sustainable Energy Reviews 13(2), 439-449.

[49] Zhi, Q., Sun, H.H., Li, Y.X., Xu, Y.R., Su, J., 2014. China's solar photovoltaic policy: An analysis based on policy instruments. Applied Energy 129, 308-319.

[50] Zhi, Q., Su, J., Ru, P., Anadon, L.D., 2013. The evolution of China's National Energy RD\&D Programs: The role of scientists in science and technology decision making. Energy Policy 61, 1568-1585.

[51] Zhao, R.R., Shi, G., Chen, H.Y., Ren, A.F., Finlow, D., 2011a. Present status and prospects of photovoltaic market in China. Energy Policy 39, 2204-2207.

[52] Zhao, Z.Y., Zhang, S.Y., Zuo, J. 2011b. A critical analysis of the photovoltaic power industry in China - From diamond model to gear model. Renewable and Sustainable Energy Reviews 9(15), 4953-4971.

[53] Zhao, Z.Y., Zhang, S.Y., Hubbard, B., Yao, X., 2013.The emergence of the solar photovoltaic power industry in China. Renewable and Sustainable Energy Reviews 21, 229-236.

[54] Zhi, Q., Sun, H., Li, Y., Xu, Y., Su, J., 2014. China's solar photovoltaic policy: An analysis 
based on policy instruments. Applied Energy 129, 308-319.

[55] Zhou, H. 2012. National Grid Company Softens its Hand and Plans to Provide Free Grid-connection to PV Projects (in Chinese). Accessed September 2, 2014: http://finance.eastday.com/Business/m2/20121024/u1a6942907.html. 


\section{Figure Captions}

Fig.1.PV Projects Installed in China Through June 24, 2014 (Source: BNEF Project Database)

Fig.2.Distribution of China's Solar Resource (Source: National Renewable Energy Laboratory (NREL))

Fig.3.Internal Rate of Return across the Four Bounding Cases and Five Cities

\section{Figures}

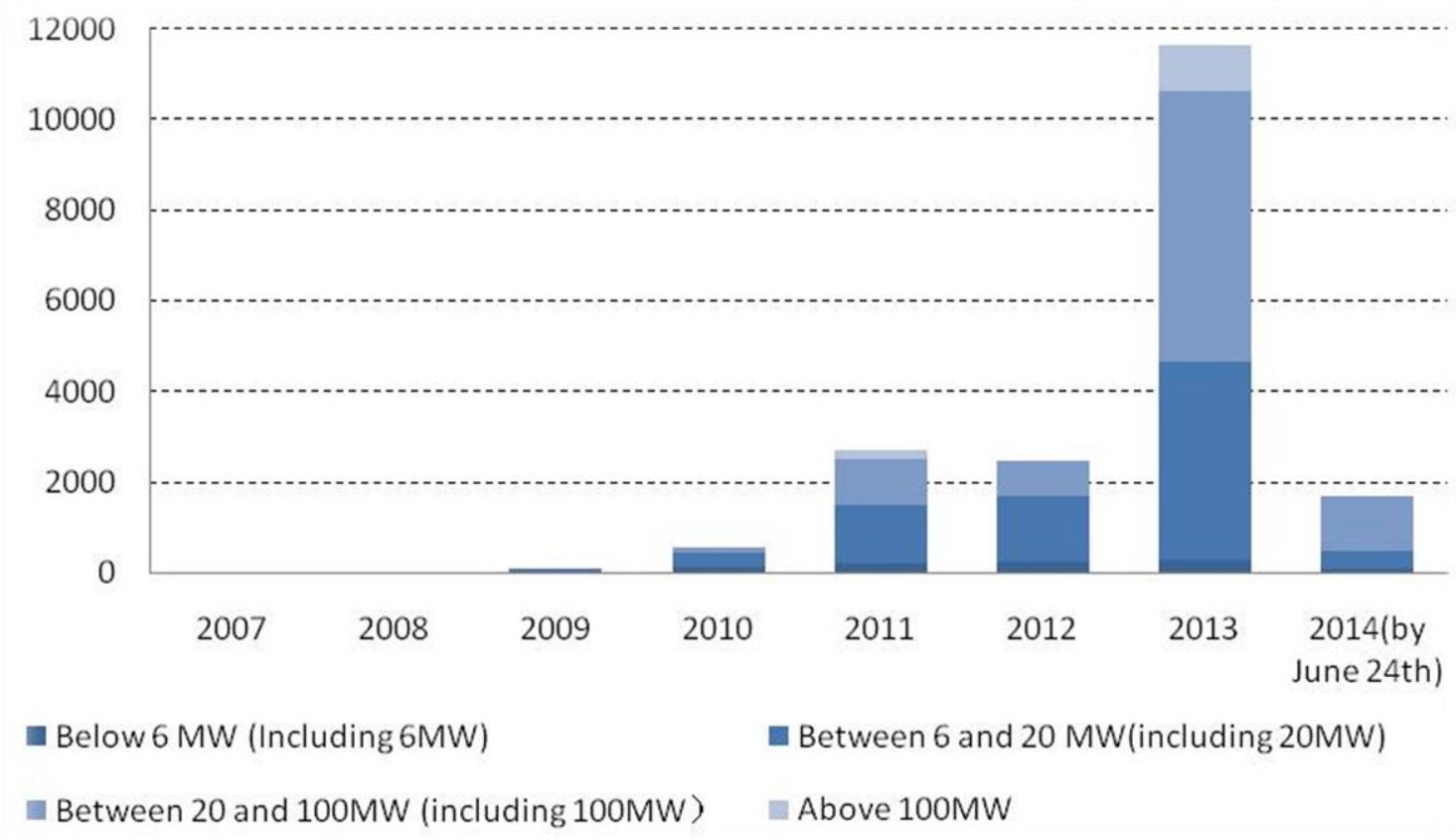

Fig.1.PV Annual Projects Installed in China, 2007 - June 24, 2014

Source: BNEF Project Database (https://www.bnef.com/core/data-explorer, subscription required to access), accessed June 24, 2014. 


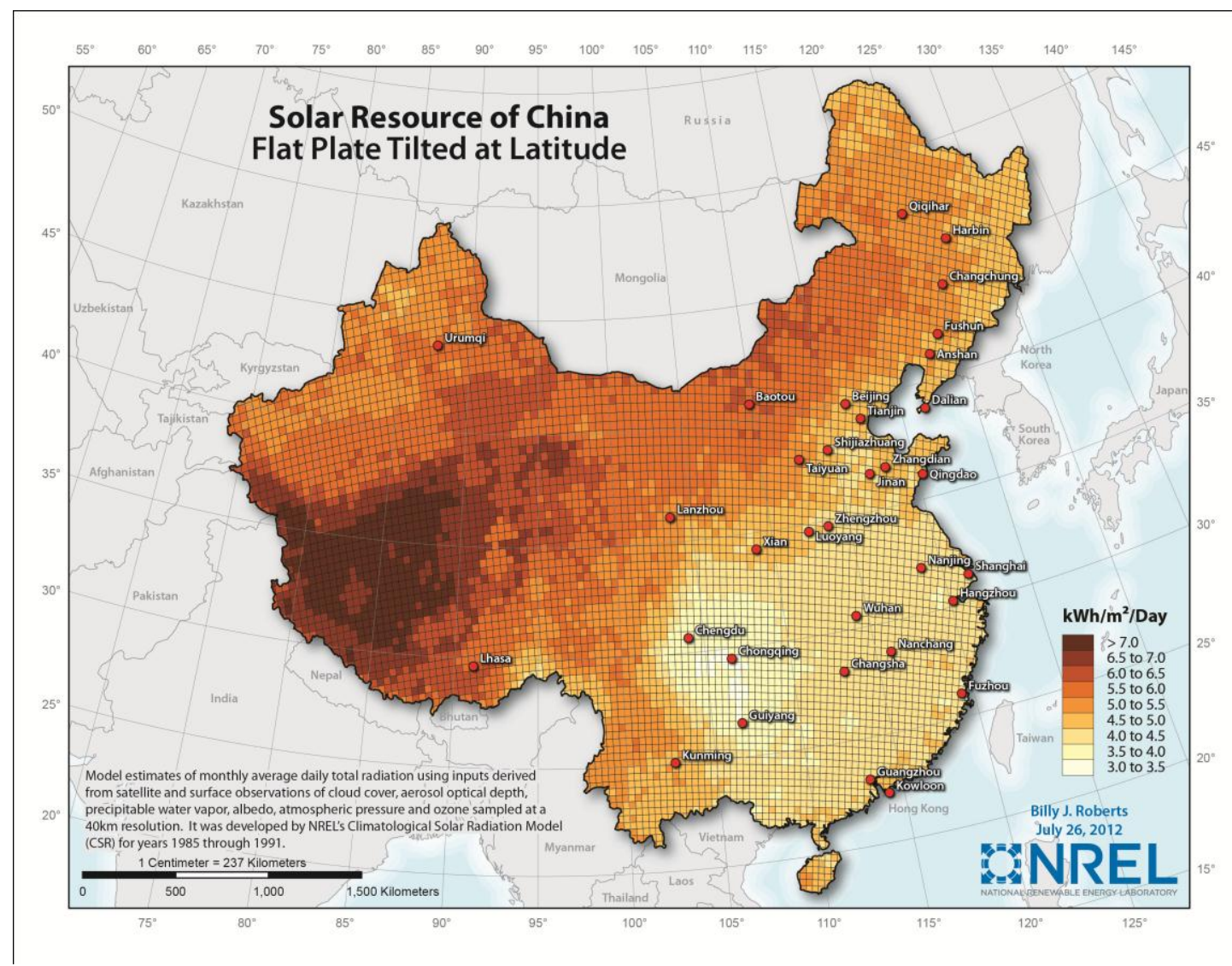

Fig.2. Distribution of China's Solar Resource

Source: National Renewable Energy Laboratory (NREL)

$25.0 \%$

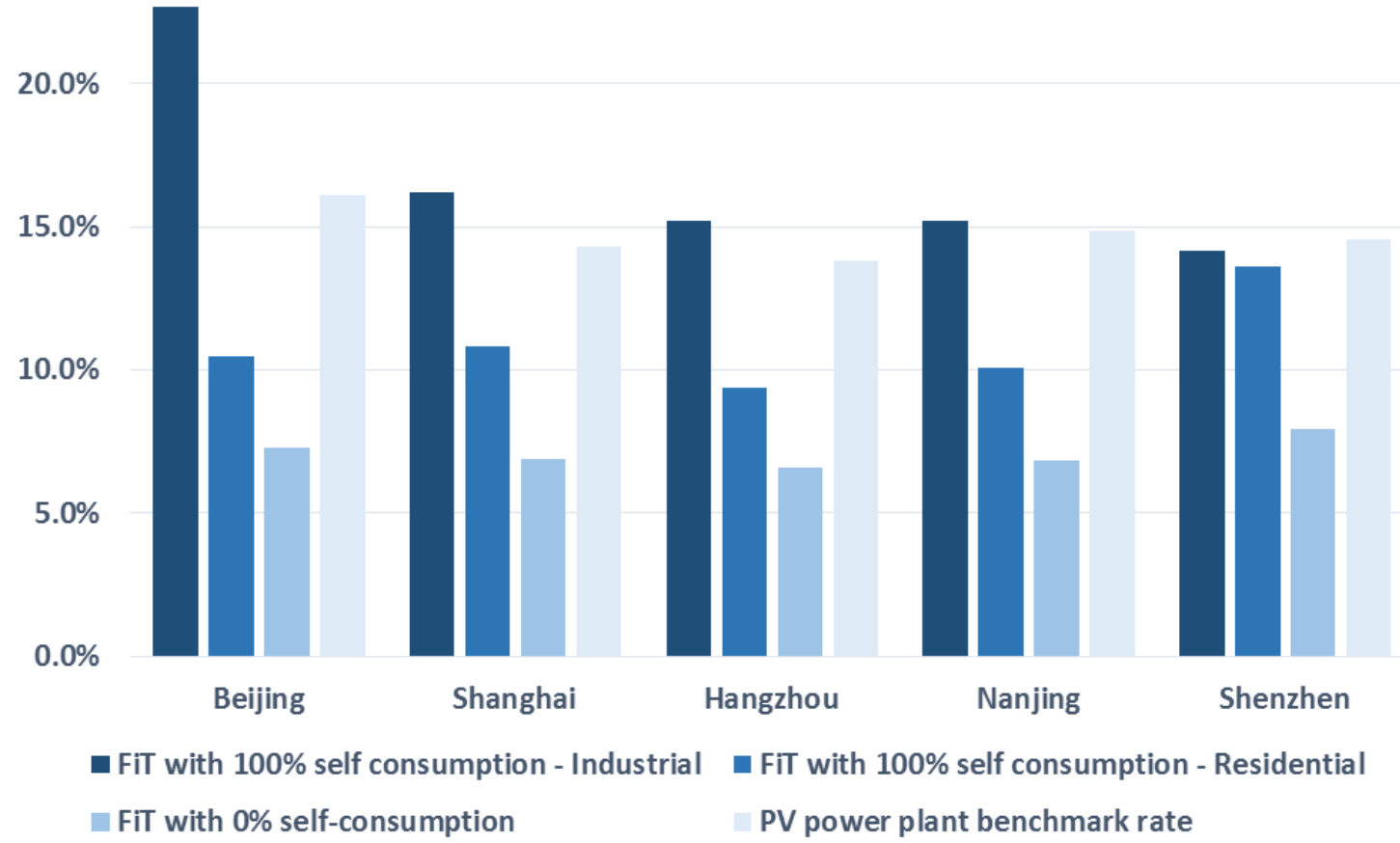

Fig.3.Internal Rate of Return across the Four Bounding Cases and Five Cities 


\section{Tables}

Table 1.PV Projects Installed, under Construction, or Permitted in China Through June 24, 2014

\begin{tabular}{|c|c|c|c|c|c|}
\hline \multicolumn{6}{|c|}{ Commissioned/partially commissioned PV projects } \\
\hline & $\leq 6 \mathrm{MW}$ & $6 \mathrm{MW}<\mathrm{X} \leq 20 \mathrm{MW}$ & $20 \mathrm{MW}<\mathrm{X} \leq 100 \mathrm{MW}$ & $\mathrm{X}>100 \mathrm{MW}$ & Total \\
\hline Number of projects & 425 & 558 & 219 & 5 & 1,207 \\
\hline $\begin{array}{l}\text { Average capacity } \\
\text { (MW) }\end{array}$ & 2.4 & 14.6 & 42.0 & 244 & 16.2 \\
\hline Capacity (GW) & 1 & 8.2 & 9.2 & 1.2 & 19.6 \\
\hline $\begin{array}{c}\text { Percentage of total } \\
\text { capacity }(\%)\end{array}$ & 5 & 42 & 47 & 6 & 100 \\
\hline \multicolumn{6}{|c|}{ Financing-secured/under-construction PV projects } \\
\hline & $\leq 6 \mathrm{MW}$ & $6 \mathrm{MW}<\mathrm{X} \leq 20 \mathrm{MW}$ & $20 \mathrm{MW}<\mathrm{X} \leq 100 \mathrm{MW}$ & $\mathrm{X}>100 \mathrm{MW}$ & Total \\
\hline Number of projects & 54 & 136 & 108 & 7 & 305 \\
\hline $\begin{array}{l}\text { Average capacity } \\
\text { (MW) }\end{array}$ & 3.5 & 14.9 & 48.8 & 176.5 & 28.6 \\
\hline Capacity (GW) & 0.2 & 2.0 & 5.3 & 1.2 & 8.7 \\
\hline $\begin{array}{c}\text { Percentage of total } \\
\text { capacity }(\%)\end{array}$ & 2 & 23 & 60 & 14 & 100 \\
\hline \multicolumn{6}{|c|}{ Permitted PV projects } \\
\hline & $\leq 6 \mathrm{MW}$ & $6 \mathrm{MW}<\mathrm{X} \leq 20 \mathrm{MW}$ & $20 \mathrm{MW}<\mathrm{X} \leq 100 \mathrm{MW}$ & $\mathrm{X}>100 \mathrm{MW}$ & Total \\
\hline Number of projects & 63 & 89 & 54 & 3 & 209 \\
\hline $\begin{array}{l}\text { Average capacity } \\
\text { (MW) }\end{array}$ & 2.7 & 14.6 & 44.3 & 293.3 & 22.7 \\
\hline Capacity (GW) & 0.2 & 1.3 & 2.4 & 0.9 & 4.7 \\
\hline $\begin{array}{c}\text { Percentage of total } \\
\text { capacity }(\%)\end{array}$ & 4 & 27 & 50 & 19 & 100 \\
\hline
\end{tabular}

Source: BNEF Project Database (https://www.bnef.com/core/data-explorer, subscription required to access), accessed June 24, 2014. 
Table 2.Top 5 Provinces for Cumulative LS PV and DG PV Installations in China Through the End of 2013

\begin{tabular}{ccccc}
\hline \multirow{2}{*}{ Ranking } & \multicolumn{2}{c}{ LS PV Installations } & \multicolumn{2}{c}{ DG PV Installations } \\
\cline { 2 - 5 } & Province & $\begin{array}{c}\text { Total capacity } \\
(\mathrm{MW})\end{array}$ & Province & $\begin{array}{c}\text { Total capacity } \\
(\mathrm{MW})\end{array}$ \\
\hline 1 & Guansu & 4,317 & Zhejiang & 425 \\
2 & Qinghai & 3,103 & Guangdong & 300 \\
3 & Xinjiang & 2,570 & Hunan & 300 \\
4 & Niangxia & 1,614 & Jiangsu & 255 \\
5 & Inner & 1,405 & Shandong & 205 \\
\hline
\end{tabular}

Source: Renewable Energy Information Management Center (2014).

Table 3.Annual DG PV Electricity Production Estimates $(\mathrm{kWh} / \mathrm{kW} / \mathrm{year})$ for the Selected Cities in China

\begin{tabular}{cc}
\hline City & Production Factor \\
\hline Beijing & 1,349 \\
Shanghai & 1,174 \\
Hangzhou & 1,140 \\
Nanjing & 1,212 \\
Shenzhen & 1,190 \\
\hline
\end{tabular}

Source: PVWatts Calculator (pvwatts.nrel.gov), accessed August 15, 2014.

Table 4.Average Value of DG PV Electricity (RMB/kWh) in the Four Bounding Cases

(a)

$\begin{array}{cc}\text { City } & 100 \% \text { self- } \\ \text { consumption } \\ \text { (industrial/commercial) }\end{array}$

(b) $100 \%$ selfconsumption (residential)

\begin{tabular}{ccccc} 
Beijing & 1.21 & (residential) & (both) & (both) \\
Shanghai & 0.97 & 0.49 & 0.39 & 0.95 \\
Hangzhou & 0.94 & 0.62 & 0.45 & 1.00 \\
Nanjing & 0.87 & 0.55 & 0.46 & 1.00 \\
Shenzhen & 0.81 & 0.55 & 0.43 & 1.00 \\
\hline
\end{tabular}

Source: Calculation based on electricity rate data from Beijing Municipal 
Commission of Development and Reform (2014), Meng (2011), Nanjing Economic Commission (2012), Hangzhou Municipal Bureau of Price (2012), NDRC (http://jgs.ndrc.gov.cn/jggs/dljg/, accessed August 28, 2014), Shanghai Municipal Commission of Economic Information (2012), and Shenzhen Online (2012).

Table 5.Summary of Economic Assumptions

\begin{tabular}{ll}
\hline Assumptions & \\
\hline Installed DG PV system cost & $9.0 \mathrm{RMB} / \mathrm{W}$ \\
System degradation & $0.5 \%$ per year \\
Inverter replacement in year 10 & $0.8 \mathrm{RMB} / \mathrm{kW}$ \\
Lifetime & 30 years \\
Electricity rate escalator & $1.0 \%$ per year \\
O\&M costs & $0.1 \mathrm{RMB} / \mathrm{kWh}$ \\
O\&M escalator & $2.5 \%$ per year \\
\hline
\end{tabular}

Table 6.Cost Breakdown for Installing a 1-10 MW DG PV System in China during $2014(\mathrm{RMB} / \mathrm{W})$

\begin{tabular}{lll}
\hline & Low & High \\
\hline Hardware & & \\
Module & 4 & 5 \\
Inverter & 0.5 & 1 \\
Other (racking, wiring, etc.) & 0.5 & 1 \\
Subtotal - Hardware & $\mathbf{5}$ & $\mathbf{7}$ \\
\hline Soft cost & & \\
Labor & 0.4 & 0.8 \\
Customer acquisition & 0.3 & 0.5 \\
Profit margin & 0.7 & 1 \\
Other (design, etc.) & 0.6 & 0.7 \\
Subtotal - Soft cost & $\mathbf{2}$ & $\mathbf{3}$ \\
\hline Total Installed Cost & $\mathbf{7}$ & $\mathbf{1 0}$ \\
\hline
\end{tabular}

Source: Based on interviews with system installers during July/August 2014. 
Table 7.Timeline for Installing a 1-10 MW DG PV System in China during 2014 (months)

\begin{tabular}{lccc}
\hline Component & Shortest & Longest & Average \\
\hline Customer acquisition & 0.5 & 6 & 2 \\
Contract (including system design & 1 & 3 & 2 \\
and procurement) $^{\mathrm{a}}$ & 1 & $4+$ & 2 \\
Permitting $^{\mathrm{a}}$ & 1 & 3 & 2 \\
Financing $^{\mathrm{a}}$ & 1 & 3 & 2 \\
Installation $_{\text {Inspection and interconnection }}$ & 0.5 & 2 & 1 \\
Total & 3 & $12+$ & 7 \\
\hline
\end{tabular}

Note: a. system design, permitting, and financing are often pursued in parallel.

Source: Based on interviews with system installers during July/August 2014.

Table8.DG PV Grid-Connection Services Provided by the National Grid Company

\begin{tabular}{ccc}
\hline & $\begin{array}{c}\text { DG PV in China } \\
\text { since 2013 }\end{array}$ & $\begin{array}{c}\text { DG PV in China before } \\
\mathbf{2 0 1 3}\end{array}$ \\
\hline Project review & Free & $\mathrm{n}$ \\
Reserve fee & Free & $10-20 \mathrm{RMB} / \mathrm{kVA} / \mathrm{month}^{\mathrm{a}}$ \\
Grid-connection (including & Free & $0.1-0.42$ million RMB per \\
meters) and inspection & connection point \\
Grid renovation and maintenance & Free & $\mathrm{n}$ \\
Meters & Free & $\mathrm{n}$ \\
\hline
\end{tabular}

Source: He (2007); Li and Li (2012); National Grid Company (2013); Liu et al. (2012).

Notes: $\mathrm{n}=$ data are unavailable; $\mathrm{a}=$ reserve fee data are for Shanxi Province; data for other provinces prior to 2013 are not available. 


\section{Appendix A}

Table A.1.Potential PV Installation in China

\begin{tabular}{ccc}
\hline Area type & Potential area & PV installed capacity potential \\
\hline $\begin{array}{c}\text { Rooftops } \\
\text { Exploitable }\end{array}$ & 4 billion $\mathrm{m}^{2}$ & $120 \mathrm{GW}$ \\
south-facing land & 5 billion $\mathrm{m}^{2}$ & $150 \mathrm{GW}$ \\
(Assuming 20\% of rooftops are covered with PV) & (Assuming 20\% of south-facing open land is covered with PV) \\
Free desert/beach & 1.2 trillionm & $1,800 \mathrm{GW}$ \\
\end{tabular}

Sources: (1) Area data from Li et al. (2009). (2) According to the product information from Yingli Solar, Trina, and JA Solar in China, the output capacities for PV modules are between $120 \mathrm{~W} / \mathrm{m}^{2}$ and $180 \mathrm{~W} / \mathrm{m}^{2}$. This article uses $150 \mathrm{~W} / \mathrm{m}^{2}$ as the average to estimate the potential installed capacity.

Table A.2.Retail Electricity Rate Structures for the Industrial/Commercial Sector $(\mathrm{RMB} / \mathrm{kWh})$

\begin{tabular}{lccccccc}
\hline Hour & Beijing & Beijing & Shanghai & Shanghai & Hangzhou & Nanjing & Shenzhen \\
\hline & Jul, Aug & Jan-Jun & Jul-Sept & Jan-Jun & & & \\
& & Sept-Dec & & Oct-Dec & & & \\
\hline 0 & 0.3658 & 0.3658 & 0.285 & 0.35 & 0.596 & 0.867 & 0.2959 \\
1 & 0.3658 & 0.3658 & 0.285 & 0.35 & 0.596 & 0.867 & 0.2959 \\
2 & 0.3658 & 0.3658 & 0.285 & 0.35 & 0.596 & 0.867 & 0.2959 \\
3 & 0.3658 & 0.3658 & 0.285 & 0.35 & 0.596 & 0.867 & 0.2959 \\
4 & 0.3658 & 0.3658 & 0.285 & 0.35 & 0.596 & 0.867 & 0.2959 \\
5 & 0.3658 & 0.3658 & 0.285 & 0.35 & 0.596 & 0.867 & 0.2959 \\
6 & 0.3658 & 0.3658 & 0.749 & 0.714 & 0.596 & 0.867 & 0.2959 \\
7 & 0.8595 & 0.8595 & 0.749 & 0.714 & 0.596 & 0.867 & 0.2959 \\
8 & 0.8595 & 0.8595 & 1.202 & 1.167 & 1.108 & 0.867 & 0.7399 \\
9 & 0.8595 & 0.8595 & 1.202 & 1.167 & 1.108 & 0.867 & 0.7399 \\
10 & 1.3782 & 1.3782 & 1.202 & 1.167 & 1.108 & 0.867 & 0.7399 \\
11 & 1.5065 & 1.3782 & 0.749 & 0.714 & 0.596 & 0.867 & 0.7399 \\
12 & 1.5065 & 1.3782 & 0.749 & 0.714 & 0.596 & 0.867 & 0.7399 \\
13 & 1.3782 & 1.3782 & 1.202 & 1.167 & 1.108 & 0.867 & 0.7399 \\
14 & 1.3782 & 1.3782 & 1.202 & 1.167 & 1.108 & 0.867 & 1.0924 \\
15 & 0.8595 & 0.8595 & 0.749 & 0.714 & 1.108 & 0.867 & 1.0924 \\
16 & 1.5065 & 0.8595 & 0.749 & 0.714 & 1.108 & 0.867 & 1.0924 \\
\hline & & & & 48 & & &
\end{tabular}




\begin{tabular}{llllllll}
\hline 17 & 0.8595 & 0.8595 & 0.749 & 0.714 & 1.108 & 0.867 & 0.7399 \\
18 & 1.3782 & 1.3782 & 1.202 & 1.167 & 1.108 & 0.867 & 0.7399 \\
19 & 1.3782 & 1.3782 & 1.202 & 1.167 & 1.406 & 0.867 & 1.0924 \\
20 & 1.3782 & 1.3782 & 1.202 & 1.167 & 1.406 & 0.867 & 1.0924 \\
21 & 0.8595 & 0.8595 & 0.749 & 0.714 & 1.108 & 0.867 & 1.0924 \\
22 & 0.8595 & 0.8595 & 0.285 & 0.35 & 0.596 & 0.867 & 0.7399 \\
23 & 0.3658 & 0.3658 & 0.285 & 0.35 & 0.596 & 0.867 & 0.7399 \\
\hline
\end{tabular}

Source: Beijing Municipal Commission of Development and Reform (2014), Meng (2011), Nanjing Economic Commission (2012), Hangzhou Municipal Bureau of Price (2012), NDRC (http://jgs.ndrc.gov.cn/jggs/dljg/ , accessed August 28, 2014), Shanghai Municipal Commission of Economic Information (2012), and Shenzhen Online (2012).

Table A.3.Retail Electricity Rate Structures for the Residential Sector (RMB/kWh)

\begin{tabular}{|c|c|c|c|c|c|}
\hline Hour & Beijing & Shanghai & Hangzhou & Nanjing & Shenzhen \\
\hline 0 & 0.4883 & 0.307 & 0.288 & 0.3583 & 0.3527 \\
\hline 1 & 0.4883 & 0.307 & 0.288 & 0.3583 & 0.3527 \\
\hline 2 & 0.4883 & 0.307 & 0.288 & 0.3583 & 0.3527 \\
\hline 3 & 0.4883 & 0.307 & 0.288 & 0.3583 & 0.3527 \\
\hline 4 & 0.4883 & 0.307 & 0.288 & 0.3583 & 0.3527 \\
\hline 5 & 0.4883 & 0.307 & 0.288 & 0.3583 & 0.3527 \\
\hline 6 & 0.4883 & 0.617 & 0.288 & 0.3583 & 0.3527 \\
\hline 7 & 0.4883 & 0.617 & 0.288 & 0.3583 & 0.3527 \\
\hline 8 & 0.4883 & 0.617 & 0.568 & 0.5583 & 0.68 \\
\hline 9 & 0.4883 & 0.617 & 0.568 & 0.5583 & 0.68 \\
\hline 10 & 0.4883 & 0.617 & 0.568 & 0.5583 & 0.68 \\
\hline 11 & 0.4883 & 0.617 & 0.568 & 0.5583 & 0.68 \\
\hline 12 & 0.4883 & 0.617 & 0.568 & 0.5583 & 0.68 \\
\hline 13 & 0.4883 & 0.617 & 0.568 & 0.5583 & 0.68 \\
\hline 14 & 0.4883 & 0.617 & 0.568 & 0.5583 & 1.1056 \\
\hline 15 & 0.4883 & 0.617 & 0.568 & 0.5583 & 1.1056 \\
\hline 16 & 0.4883 & 0.617 & 0.568 & 0.5583 & 1.1056 \\
\hline 17 & 0.4883 & 0.617 & 0.568 & 0.5583 & 0.68 \\
\hline 18 & 0.4883 & 0.617 & 0.568 & 0.5583 & 0.68 \\
\hline 19 & 0.4883 & 0.617 & 0.568 & 0.5583 & 1.1056 \\
\hline 20 & 0.4883 & 0.617 & 0.568 & 0.5583 & 1.1056 \\
\hline 21 & 0.4883 & 0.617 & 0.568 & 0.3583 & 1.1056 \\
\hline 22 & 0.4883 & 0.307 & 0.288 & 0.3583 & 0.68 \\
\hline 23 & 0.4883 & 0.307 & 0.288 & 0.3583 & 0.68 \\
\hline
\end{tabular}

Source: Beijing Municipal Commission of Development and Reform (2014), Meng (2011), Nanjing Economic Commission (2012), Hangzhou Municipal Bureau of Price (2012), NDRC (http://jgs.ndrc.gov.cn/jggs/dljg/, accessed August 28, 2014), Shanghai Municipal Commission of 
Economic Information (2012), and Shenzhen Online (2012).

Table A.4.Evolution of Key Policies for DG PV Deployment in China

\begin{tabular}{|c|c|c|}
\hline Date & Policy Title & Publishers \\
\hline 2009.07 & $\begin{array}{l}\text { Notice on the Implementation of the Golden Sun Demonstration } \\
\text { Project }\end{array}$ & $\begin{array}{l}\text { MOF, MOST, } \\
\text { NEA }\end{array}$ \\
\hline 2010.09 & $\begin{array}{l}\text { Notice on Strengthening Construction Management of the Golden } \\
\text { Sun Demonstration Projects and the Building Solar Energy } \\
\text { Application Demonstration Program }\end{array}$ & $\begin{array}{l}\text { MOF, MOST, } \\
\text { NEA, MHURD }\end{array}$ \\
\hline 2012.01 & $\begin{array}{l}\text { Notice on Implementing the Golden Sun Demonstration Projects } \\
\text { Well in } 2012\end{array}$ & $\begin{array}{l}\text { MOF, MOST, } \\
\text { NEA }\end{array}$ \\
\hline 2012.02 & $12^{\text {th }}$ Five Year Industry Development of Solar PV Industry & MIIT \\
\hline 2012.03 & $\begin{array}{l}\text { Interim Measures for Additional Subsidy Funds of Renewable } \\
\text { Energy Tariff }\end{array}$ & $\begin{array}{l}\text { MOF, NDRC, } \\
\text { NEA }\end{array}$ \\
\hline 2012.03 & $\begin{array}{l}12^{\text {th }} \text { Five Year Special Planning for S\&T Development of Solar } \\
\text { Power Generation }\end{array}$ & MOST \\
\hline 2012.05 & $\begin{array}{l}\text { Notice on the Application of New Energy Demonstration City and } \\
\text { Industrial Park }\end{array}$ & NEA \\
\hline 2012.06 & $\begin{array}{l}\text { Implementing Opinions on Encouraging and Guiding Private } \\
\text { Capitals to Further Expand the Field of Energy Investment }\end{array}$ & NEA \\
\hline 2012.07 & $12^{\text {th }}$ Five Year Development Plan of Solar Electricity Generation & NEA \\
\hline 2012.08 & $12^{\text {th }}$ Five Year Development Plan of Renewable Energy & NEA \\
\hline 2012.08 & $\begin{array}{l}\text { Notice on Improving Related Policies of Renewable Energy } \\
\text { Building Integration and Adjusting Management Modes of Fund } \\
\text { Allocation }\end{array}$ & MOF, MHURD \\
\hline 2012.09 & Notice on Application of DG PV Scaling Demonstration Area & NEA \\
\hline 2012.10 & $\begin{array}{l}\text { Notice on Providing Grid Connection Service for DG PV Projects } \\
\text { (Provisional) }\end{array}$ & National Grid \\
\hline 2012.10 & $\begin{array}{l}\text { Some Opinions Related to Promoting Grid Connection } \\
\text { Management of DG PV Installation (Provisional) }\end{array}$ & National Grid \\
\hline 2012.10 & $\begin{array}{l}\text { The Provisions on Technology of DG PV Grid Connection } \\
\text { (Provisional) }\end{array}$ & National Grid \\
\hline 2012.10 & $\begin{array}{l}\text { Notice on the Policy Formation of Construction in Areas Without } \\
\text { Electricity Access and Construction Application Policy and the } \\
\text { Adjustment of the Management Mode of Fund Allocation }\end{array}$ & NEA \\
\hline 2012.11 & $\begin{array}{l}\text { Declaration on Organizing the Applications of Golden Sun } \\
\text { Demonstration Projects and BIPV Projects }\end{array}$ & $\begin{array}{l}\text { MOF, MOST, } \\
\text { MHURD, NEA }\end{array}$ \\
\hline 2012.11 & $\begin{array}{l}\text { Notice on Renewable Energy Price Subsidies and Quotas Trading } \\
\text { Scheme }\end{array}$ & NEA, SERC \\
\hline 2013.01 & $12^{\text {th }}$ Five Year Plan of Energy Development & State Council \\
\hline 2013.2 & $\begin{array}{l}\text { Opinions on Grid-Connection Service Prepared for the DG PV } \\
\text { Development }\end{array}$ & National Grid \\
\hline
\end{tabular}




\begin{tabular}{|c|c|c|}
\hline 2013.06 & $\begin{array}{l}\text { Notice on Bringing the Subsidies of Golden Sun Demonstration } \\
\text { Projects to Account }\end{array}$ & MOF \\
\hline 2013.06 & Work Scheme of DG PV Demonstration Zones & NEA \\
\hline 2013.07 & $\begin{array}{l}\text { Some Opinions on Promoting the Healthy Development of the } \\
\text { Photovoltaic Industry }\end{array}$ & State Council \\
\hline 2013.07 & Interim Measures for the Management of Distributed Generation & NDRC \\
\hline 2013.07 & $\begin{array}{l}\text { Notice on Implementing the Electricity Subsidy Policy Based on } \\
\text { Actual DG PV Power Generation }\end{array}$ & MOF \\
\hline 2013.07 & $\begin{array}{l}\text { Notification on Supervision Survey of Wind Power and Solar } \\
\text { Absorption }\end{array}$ & NEA \\
\hline 2013.08 & $\begin{array}{l}\text { Notice on Issues Related to the Adjustment of Additional } \\
\text { Renewable Energy Tariff Standards and Environment-Protected } \\
\text { Electricity Price }\end{array}$ & NDRC \\
\hline 2013.08 & $\begin{array}{l}\text { Opinions on Supporting Financial Service for DG PV } \\
\text { Development }\end{array}$ & $\begin{array}{l}\text { NEA, China } \\
\text { Development } \\
\text { Bank }\end{array}$ \\
\hline 2013.08 & $\begin{array}{l}\text { Notice about Playing the Role of the Price Lever to Promote the } \\
\text { Healthy Development of Photovoltaic Industry }\end{array}$ & NDRC \\
\hline 2013.08 & $\begin{array}{l}\text { Interim Measures for the Project Management of Photovoltaic } \\
\text { Power Station }\end{array}$ & NEA \\
\hline 2013.09 & $\begin{array}{l}\text { Notice on Value-Added Tax Policy of Photovoltaic Power } \\
\text { Generation }\end{array}$ & MOF, SAT \\
\hline 2013.09 & Standard Condition of Photovoltaic Manufacturing Industry & MIIT \\
\hline 2013.10 & $\begin{array}{l}\text { Notice on Issuing Several Opinions to Develop Distributed Power } \\
\text { Generation }\end{array}$ & NEA \\
\hline 2013.10 & $\begin{array}{l}\text { Interim Measures for Issuing Management of Photovoltaic } \\
\text { Manufacturing Industry Standards }\end{array}$ & MIIT \\
\hline 2013.11 & $\begin{array}{l}\text { Interim Measures for the Project Management of DG PV } \\
\text { Installation }\end{array}$ & NEA \\
\hline 2013.11 & $\begin{array}{l}\text { Notice on the Exemption of Government Funds for the } \\
\text { Self-consumed Electricity Generated by DG PV Projects }\end{array}$ & MOF \\
\hline 2014.01 & $\begin{array}{l}\text { Notice on Posting the First Group of Cites to Build New Energy } \\
\text { Demonstration City (Including Industrial Park) }\end{array}$ & NEA \\
\hline 2014.01 & Notice on the Construction Scale of New Added DG PV in China & NEA \\
\hline 2014.04 & $\begin{array}{l}\text { Circular on Issues Concerned with Clarifying Clear Power } \\
\text { Business License Management }\end{array}$ & NEA \\
\hline 2014.05 & $\begin{array}{l}\text { Notice on Strengthening Information Counting and Reporting of } \\
\text { DG PV Installations }\end{array}$ & NEA \\
\hline 2014.06 & $\begin{array}{l}\text { Notice on Strengthening the Information Collection and Reporting } \\
\text { of New Energy Demonstration Cities }\end{array}$ & NEA \\
\hline 2014.06 & $\begin{array}{l}\text { On Issues Related to Invoice Provided by National Grid } \\
\text { Companies When They Purchase DG PV Electricity }\end{array}$ & SAT \\
\hline 2014.09 & Notice on Further Implementation of Policies Relevant to & NEA \\
\hline
\end{tabular}




\section{Distributed Photovoltaic Power Generation}

Source: PV-Tech (2014), NDRC Document Resource Center (http://www.sdpc.gov.cn/, Accessed September 17, 2014), and Chinese Renewable Energy Industry Association (http://www.chnreia.org/fagui/, Accessed September 20, 2014).

Notes: MHURD $=$ Ministry of Housing and Urban-Rural Development; SAT $=$ State Administration of Taxation; SERC $=$ State Electricity Regulatory Commission; MIIT $=$ Ministry of Industry and Information Technology.

Table A.5. Provincial and Local Subsidies for PV Installations, as of September 4, 2014

\begin{tabular}{|c|c|}
\hline Province & Level of Subsidies \\
\hline Jiangxi Province & $\begin{array}{l}\text { National: } 0.42 \mathrm{RMB} / \mathrm{kWh} \text {; } \\
\text { Provincial: } 0.2 \mathrm{RMB} / \mathrm{kWh} \\
\text { Provincial specific funding: } 4 \mathrm{RMB} / \mathrm{W} \text { for the first program; } 3 \mathrm{RMB} / \mathrm{W} \text { for the } \\
\text { second program (10,000 Roof Demonstration) (2013) }\end{array}$ \\
\hline Shandong Province & $\begin{array}{l}1.2 \mathrm{RMB} / \mathrm{kWh} \text { (including the national subsidy, for PV projects between } \\
\text { 2013-2015) (2013) }\end{array}$ \\
\hline Henan Province & $\begin{array}{l}\text { Luoyang City } \\
0.1 \mathrm{RMB} / \mathrm{W} \text { for DG PV installations before 2015, giving priority to local PV } \\
\text { modules (2013) }\end{array}$ \\
\hline Anhui Province & $\begin{array}{l}\text { Hefei City } \\
0.25 \mathrm{RMB} / \mathrm{kWh} \text { for roofs and BIPV for } 15 \text { years (not including national } \\
\text { subsidies) } \\
\text { For residential PV projects: } 2 \mathrm{RMB} / \mathrm{W} \text {, no local FIT subsidy (2013) }\end{array}$ \\
\hline Jiangsu Province & $\begin{array}{l}1.2 \mathrm{RMB} / \mathrm{kWh} \text { in } 2014 ; 1.15 \mathrm{RMB} / \mathrm{kWh} \text { in } 2015 \text { (for projects without national } \\
\text { subsidies) (2012) }\end{array}$ \\
\hline Heibei Province & $\begin{array}{l}1.3 \mathrm{RMB} / \mathrm{kWh} \text { for PV projects starting operating by the end of } 2014 \text {, plus the size } \\
\text { of the project is above } 1 \mathrm{MW} \text { and without national subsidies; } 1.2 \mathrm{RMB} / \mathrm{kWh} \text { for } \\
\text { similar PV projects which started operating by the end of } 2015 \text {. FIT lasts three } \\
\text { years (2013) }\end{array}$ \\
\hline Shanghai & $\begin{array}{l}0.25 \mathrm{RMB} / \mathrm{kWh} \text { for commercial; } \\
0.4 \mathrm{RMB} / \mathrm{kWh} \text { for residential (2014) }\end{array}$ \\
\hline \multirow[t]{2}{*}{ Zhejiang Province } & $\begin{array}{l}\text { National subsidy: } 0.42 \mathrm{RMB} / \mathrm{kWh} \text {; } \\
\text { Provincial subsidies: } 0.1 \mathrm{RMB} / \mathrm{kWh}(2013)\end{array}$ \\
\hline & $\begin{array}{l}\text { Wenzhou City (2013) } \\
0.05 \mathrm{RMB} / \mathrm{kWh} \text { for } 5 \text { years }\end{array}$ \\
\hline
\end{tabular}


Commercial: $0.15 \mathrm{RMB} / \mathrm{kWh}$ for projects installed and starting into operation in 2014

Residential: $0.1 \mathrm{RMB} / \mathrm{kWh}$ for projects installed and starting into operation in 2015 ;

---Yongjia County (2013)

Residential: $0.3 \mathrm{RMB} / \mathrm{kWh}$ for 5 years.

Country-level subsidies: 0.40 RMB/kWh for non-residential PV projects with size more than $50 \mathrm{~kW}$

Jiangxi City (2013)

0.1 RMB/kWh (for $200 \mathrm{MW}$ PV installations in the city), lasting 3 years

\section{---Xiuzhou Region}

$1 \mathrm{RMB} / \mathrm{W}$ for national PV demonstration project (100\% subsidies for PV project with more than $30 \%$ equipment purchased locally; $80 \%$ subsidies for PV project with less than $30 \%$ equipment purchased locally)

Haining City (2013)

$0.35 \mathrm{RMB} / \mathrm{kWh}$ (not including national and provincial subsidies) for PV projects above $0.1 \mathrm{MW}$ which start to operate by the end of 2014 ;

$0.3 \mathrm{RMB} / \mathrm{W}$ for providers of roof resource

\section{Tongxiang City}

1.5 RMB/W for non-national subsidized PV projects.

$0.3 \mathrm{RMB} / \mathrm{kWh}$ for projects into operation in 2014 for the first two years and then

$0.2 \mathrm{RMB} / \mathrm{kWh}$ for the next three years

$30 \mathrm{RMB} / \mathrm{m}^{2}$ for roof renters

If procuring local PV projects, giving $15 \%$ discount of procurement price

\section{Hangzhou City-Xiaoshan District}

City subsidies: 0.1 RMB/kWh for 2014-2015

$0.2 \mathrm{RMB} / \mathrm{kWh}$ for more than $30 \mathrm{~kW}$ sized $\mathrm{PV}$ projects which is within demonstration plan but is not subsidized.

\section{Fuyang City}

$0.3 \mathrm{RMB} / \mathrm{kWh}$ for the first two years; $0.2 \mathrm{RMB} / \mathrm{kWh}$ for the next three years

\section{Quzhou City--Nongyou Country}

$0.3 \mathrm{RMB} / \mathrm{kWh}$

\section{--Jiangshan}

$0.3 \mathrm{RMB} / \mathrm{W}$ for $1 \mathrm{MW}$ or larger PV projects

0.3 RMB/kWh for PV projects which have not gained any subsidies from national and provincial government

(1) Utility-scale: $0.2 \mathrm{RMB} / \mathrm{kWh}$ (not including the national and provincial subsidies) 
(2) Distributed: $0.3 \mathrm{RMB} / \mathrm{W}$, and giving another $0.15 \mathrm{RMB} / \mathrm{kWh}$ for self consumed projects

(3) $10 \mathrm{RMB} / \mathrm{m}^{2}$ to encourage enterprise which consumes more than 1,000 ton equivalent coal per year to use or rent roofs and install PV projects.

\section{Ji'An County}

$0.2 \mathrm{RMB} / \mathrm{kWh}$ for two years.

$15 \mathrm{RMB} / \mathrm{m}^{2}$ for roofs used by enterprises

\section{Shaoxing City}

$5 \%$ investment subsidies but no more than 1.5 million RMB.

$0.2 \mathrm{RMB} / \mathrm{kWh}$ (not including national and provincial subsides) for 5 years.

\begin{tabular}{l|l}
\hline Shaanxi Province & Shangluo City \\
$0.1 \mathrm{RMB} / \mathrm{W}$ and $0.05 \mathrm{RMB} / \mathrm{kWh}$ for PV projects using local PV products \\
& $\begin{array}{l}\text { Prize equivalent to } 5 \% \text { of private income tax back to enterprises which install } \\
\text { more than } 50 \mathrm{MW} \text { or maintain more than } 100 \mathrm{MW} \text { PV projects } \\
5 \% \text { local tax refund to enterprises which register locally and provide balance of } \\
\text { systems. }\end{array}$ \\
\hline Shan Xi Province & 2 GW PV installed capacity by $2015 ; 5 \mathrm{GW}$ by 2020 \\
\hline
\end{tabular}

Source: He and Liu (2014), PV-Tech (2014), Light Energy Publisher (2014), China Cell Website (2014), and OFweek (2014). 